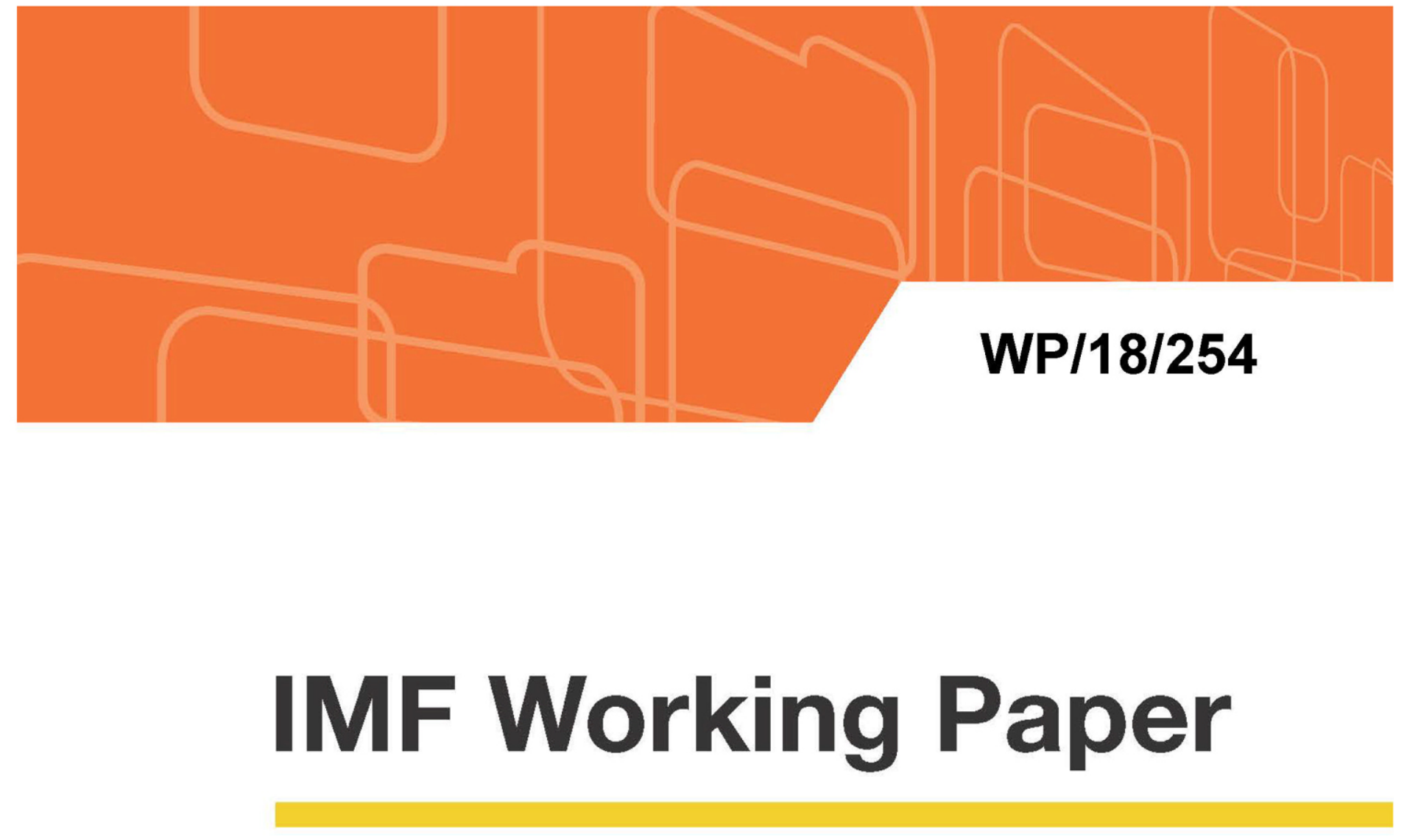

\title{
Structural Quarterly Projection Model for Belarus
}

\author{
By Karel Musil, Mikhail Pranovich and Jan Vlcek
}

IMF Working Papers describe research in progress by the author(s) and are published to elicit comments and to encourage debate. The views expressed in IMF Working Papers are those of the author(s) and do not necessarily represent the views of the IMF, its Executive Board, or IMF management. 


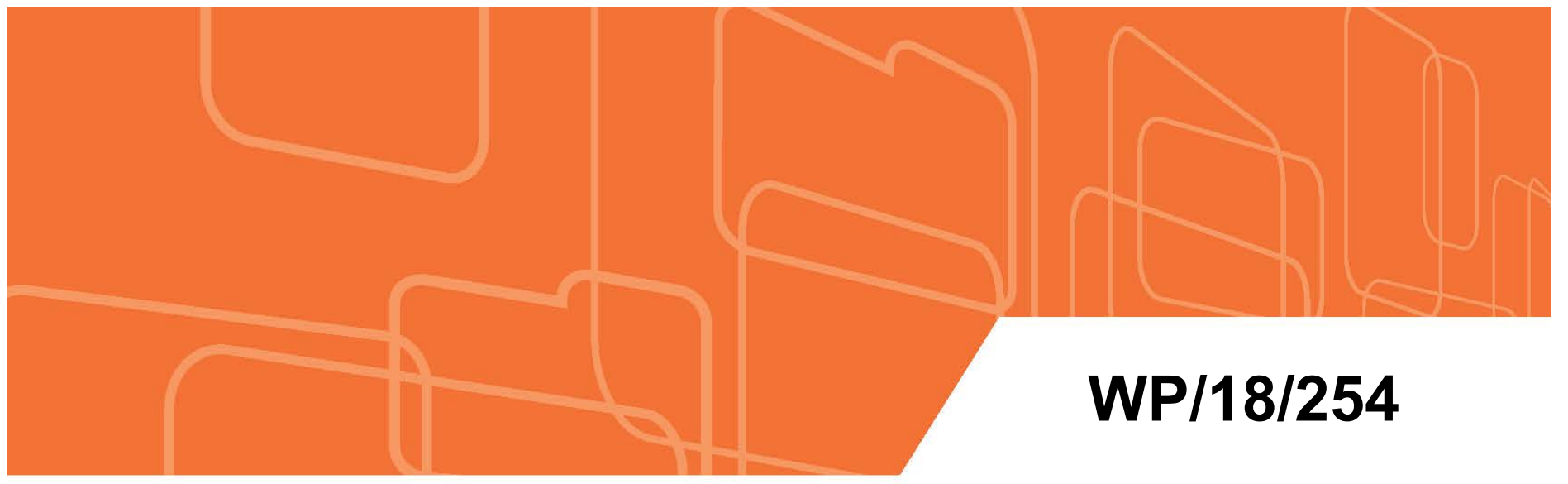

\title{
IMF Working Paper
}

\section{Structural Quarterly Projection Model for Belarus}

\author{
By Karel Musil, Mikhail Pranovich and Jan Vlcek
}

IMF Working Papers describe research in progress by the author(s) and are published to elicit comments and to encourage debate. The views expressed in IMF Working Papers are those of the author(s) and do not necessarily represent the views of the IMF, its Executive Board, or IMF management.

I N T E R N A T I O N A L M O N E T A R Y F U N D 
(C) 2018 International Monetary Fund

$\mathrm{WP} / 18 / 254$

\section{IMF Working Paper}

Institute for Capacity Developments

\section{Structural Quarterly Projections Model for Belarus ${ }^{1}$}

Prepared by Karel Musil, Mikhail Pranovich, and Jan Vlcek

Authorized for distribution by Valerie Cerra (ICD)

December 2018

IMF Working Papers describe research in progress by the author(s) and are published to elicit comments and to encourage debate. The views expressed in IMF Working Papers are those of the author(s) and do not necessarily represent the views of the IMF, its Executive Board, or IMF management.

\footnotetext{
Abstract

Belarusian authorities contemplate transiting to inflation targeting. The paper suggests a small structural model at the core of the forecasting and policy analysis system. A well-researched canonical structure of Berg, A., Karam, P. and D. Laxton (2006) is extended to capture specifics of Belarusian economy and macroeconomic policy. The modified model's policy block reflects a monetary targeting regime and allows for transition from it to an interest-rate-based framework. Adding wages, directed lending and dollarization allow for studying implications of activist wage policy, state program lending, and dollarization for macroeconomic stability and the strength of the policy transmission mechanism.

JEL Classification Numbers: E47, E52, C54

Keywords: Belarus, Quarterly Projection Model, Monetary Policy, Dollarization, Nominal Wages, Fiscal Impulse

Authors’ E-Mails: kar.musil@gmail.com; mpranovich@imf.org; janvlcekatcz@gmail.com

${ }^{1}$ Technical assistance and customized training missions, which led to the development of this model, were provided to the National bank of Belarus within the project on Building Capacity in Monetary Policy Modeling in Belarus. This project has been jointly delivered by MCM, ICD and JVI in 2017 and 2018, and financed by the Swedish International Development Cooperation Agency (SIDA). Authors gratefully acknowledge guidance of Nils Maehle (Senior Economist, MCM) during the project implementation and comments he provided on the draft of this paper. We are thankful to Maria Sviderskaya (Economist, IMF Resident Representative Office in Belarus), Beata Jajko (Senior Economist, EUR), Dora Benedek (Senior Economist, EUR) and Alexander Zaborovskiy (Advisor to the Executive Director) for their comments, help with data, discussions and support of this project and the paper.
} 
Table of Contents

ABSTRACT $\underline{2}$

I. INTRODUCTION 4

II. BELARUSIAN ECONOMY AND MACROECONOMIC POLICY: STYLIZED FACTS $\underline{4}$

A. Monetary policy modernization

B. Dollarization __ $\underline{5}$

C. Wage policy _

D. Fiscal support and directed lending ___ $\underline{8}$

E. Trade links with Russia and European Union ___ $\underline{9}$

F. Regulated Prices

III. STRUCTURE AND FEATURES OF THE QPM FOR BELARUS ___ 11

A. Monetary policy and exchange rate framework __ 11

B. Dollarization __ 14

C. Wages _ـ 15

D. Fiscal and Directed Lending Impulses ___ $\underline{16}$

E. Foreign block _ 17

F. Supply block _

G. Linking pieces together in the demand block __ $\underline{19}$

IV. MODEL CALIBRATION AND PROPERTIES ___ 19

V. MODEL SIMULATIONS AND HISTORICAL DATA INTERPRETATION __ $\underline{24}$

VI. CONCLUSIONS _ _ $\underline{30}$ 


\section{INTRODUCTION}

The National Bank of the Republic of Belarus (NBRB) seeks to modernize its monetary policy framework and establish forecasting and policy analysis tools and processes. In early-2018 the NBRB announced switching to the interest-rate-based and forward-looking monetary policy with an increasing role of inflation forecasts. ${ }^{2}$ In line with this strategy, the NBRB seeks to develop a framework for forecasting and policy analysis (FPAS) with a structural macroeconomic model at its core ${ }^{3}$.

The paper presents a structural quarterly projection model (QPM) for Belarus. It describes (i) the model structure, (ii) non-standard features to match the stylized facts of the Belarus economy and macroeconomic policy, (iii) calibration of the model, and (iv) model properties. We focus on highlighting the differences of the QPM for Belarus with respect to the workhorse canonical QPM presented in Berg et al. (2006a).

A relatively rich model structure provides an analytical tool for evaluating counter-factual policy scenarios and policy simulations under a comprehensive range of policy options. For example, the QPM allows projecting and comparing macroeconomic outcomes when the central bank transits from money to inflation targeting and higher to lower degree of the exchange rate management, i.e. to a more flexible exchange rate.

The rest of the paper comprehensively documents the main features and properties of the QPM for Belarus. We discuss key stylized facts of the Belarus economy policy conduct in section II, and present how these facts are captured in the specific model features and structure in section III. In section IV we discuss calibration of the model and calibration checks. We show results of several simulation exercises demonstrating implications of the monetary policy regime and model properties in section $\mathrm{V}$.

\section{Belarusian Economy and Macroeconomic Policy: Stylized Facts}

Several key stylized facts of Belarusian economy are reflected in the model to ensure its relevance for macroeconomic policy debates and monetary policy making. The facts are related to (i) changes in the monetary policy framework, (ii) dollarization, (iii) wage policy, (iv) subsidized directed lending, (v) trade links and (vi) regulated prices.

\footnotetext{
${ }^{2}$ Chapter II of Monetary Policy Guidelines for 2018: http://www.nbrb.by/engl/Legislation/documents/2018_E.pdf.

${ }^{3}$ See CNB (2003) for an example of FPAS.
} 


\section{A. Monetary policy modernization}

The NBRB plans to transit to forward-looking monetary policy and strengthen the policy framework. The bank moved from the de jure crawling peg to the managed floating exchange rate regime in $2015^{4}$. Foreign exchange (FX) interventions are broadly rules-based, guided by a wide crawling band allowing smoothing and opportunistic build-up of reserves. The central bank officially operates under the money targeting with broad money as an intermediate target. The bank sets a medium-term objective for inflation and aims to keep it near 5 percent by 2020 .

The Belarusian monetary authorities expressed their intention to move to the inflation targeting over the next few years, which is also in line with recommendation of IMF's Article IV missions. ${ }^{5}$ As a first step, the NBRB has announced moving to the interest-rate-based policy implementation in 2018. In modern central banks this change means using interest rates as a control variable that anchors the money market interest rate and better signals monetary policy actions. At the same time this change in policy implementation poses and transition to inflation targeting inevitably should lead to a diminishing role of money as intermediate policy target. ${ }^{6}$ Given the likely transition to a more forward-looking monetary policy strategy, we allow for elements in our model that incorporate transition from money to inflation targeting and a more flexible exchange rate.

\section{B. Dollarization}

The Belarusian economy is highly dollarized which is reflected in a large share of foreign currency in both newly originated loans and deposits, as well as in their respective stocks ${ }^{7}$. In the last decade to 2017 the share of dollarized household and corporate deposits in the total stock has doubled from about 35 to 70 percent (Figure 1.A) driven by large exchange rate realignments ${ }^{8}$. On average in 2017 , the share of foreign currency in the flow of newly originated deposits stood at about 64 percent (Figure 1.B). It is most likely the case of the financial dollarization, because private entities and corporations hold foreign denominated assets to mitigate adverse effects of potential depreciation of the Belarusian ruble. We consider it

\footnotetext{
${ }^{4}$ See IMF (2017).

${ }^{5}$ See IMF (2016).

${ }^{6}$ This modernization is also in line with general reconsideration of money growth targets under Fund supported programs as discussed in IMF (2014) and IMF (2015).

${ }^{7}$ Besides dollarization, Kharitonchik and Dmitriev (2018) find relatively strong pass-through from the exchange rate to inflation and real economic activity.

${ }^{8}$ Both household and corporations hold FX loans but the main bulk, about 75 percent, consists of corporate loans.
} 
important to capture dollarization in our model because it makes monetary policy transmission mechanism complex and hence poses a question about monetary policy efficiency in such circumstances.

Figure 1.A: Shares of FX denominated deposits in the total stock of deposits, percent

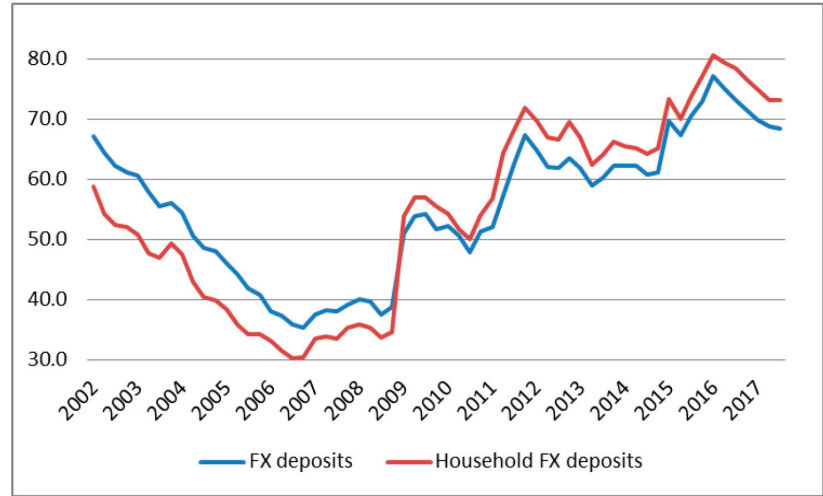

Figure 1.B: Shares of new FX denominated deposits in total new deposits, percent ${ }^{9}$

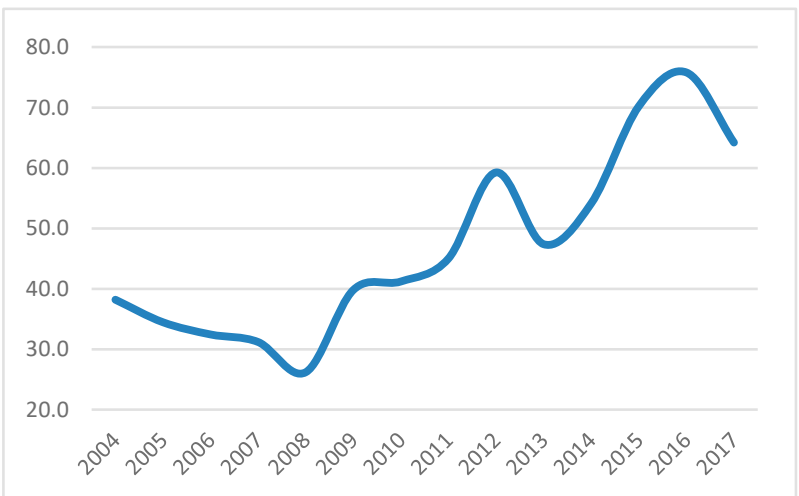

Source: NBRB and authors' calculations

Dollarization affects demand via stocks as well as flows. For example, any depreciation raises the ruble value of the stock of foreign exchange deposits and consequently the wealth of depositors, but at the same time it increases ruble equivalent of the stock of FX-denominated debt. We assume that agents hold FX deposits primarily as insurance against depreciation and therefore we consider the positive wealth effects on consumption and on the real growth as tiny: neither households nor firms start to spend more once the ruble value of their deposits is higher. ${ }^{10}$ On the contrary, depreciation can have a larger negative impact on demand if unhedged borrowers have to reallocate more ruble resources from financing demand to servicing the stock of FX-denominated loans. However, to account for the impact of the exchange rate movements on demand via revaluation of FX-denominated assets we would need to substantially extend the model and introduce the dynamics of the stock of foreign loans, the cost of loans service and their link to demand.

\footnotetext{
9 The flow numbers are adjusted for the difference in duration. For example, a new 1-month BYN deposit opened 12 times over the same year does not create a flow which is 12 times higher than the equivalent amount of a deposit opened once and for a whole year. Hence, we weight new deposits by their average duration to achieve comparability of flows. Then deposits opened for 1 month and less have a weight of 1/12, for 1-3 months have a weight of $2 / 12$, for 3-6 months $4.5 / 12$ and so on.

${ }^{10}$ In fact, they might reduce their consumption in order to increase their foreign exchange deposits if they expect further depreciation.
} 
In the current version of the model we focus only on the effect of dollarization on aggregate monetary conditions and aggregate demand via the flows or, in other words, via newly originated loans and deposits. Indeed, relatively large dollarization of flows means that only a part of asset prices depends on changes in the short-term domestic interest rate, which independent central banks are usually able to steer. Hence, the monetary policy transmission via the domestic interest rate channel is weaker.

The monetary conditions in the dollarized part of flows are affected by expected changes in the exchange rate and hence the exchange rate channel still transmits the policy signal. The effectiveness of policy transmission then depends on how strongly the central bank manages the nominal exchange rate. If the exchange rate is more flexible - i.e., less tightly managed - and therefore is sensitive to changes in the domestic interest rate, then changes in the domestic policy rate will impact the expected ruble cost a new FX loan or the expected ruble rate of return on a new FX deposit. In our QPM we let ruble costs of the newly originated FX assets to enter aggregate monetary conditions and hence account for dollarization of asset flows. We note that our QPM can be applied to study the effect of the varying degrees of exchange rate flexibility on macroeconomic outcomes of monetary policy in dollarized economy ${ }^{11}$.

\section{Wage policy}

For most of the 2000s, the Belarusian government pursued activist wage policy by setting nominal wage targets - often as an equivalent in US dollars - for state owned enterprises (SOEs) and state agencies (Figure 2). Given a still dominant role of the state sector and spill-overs to the

Figure 2: Nominal wages, average per annum, in USD equivalent

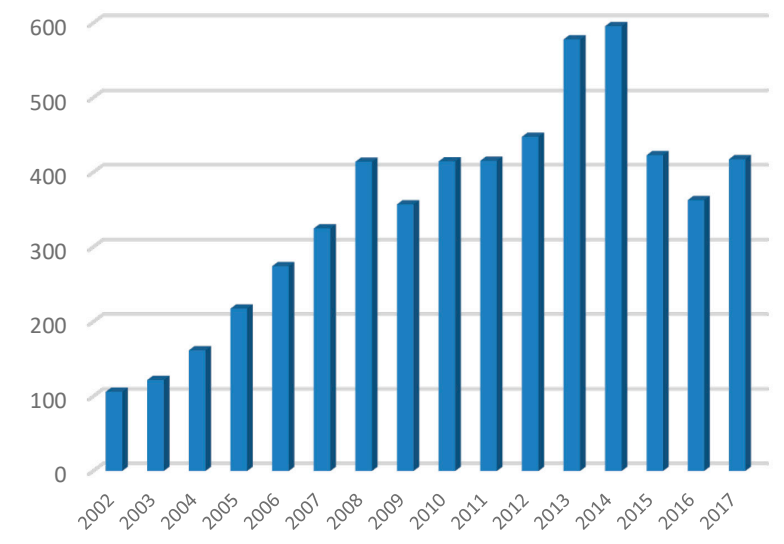

Source: NBRB and authors' calculations private sector, the wage targets had a strong impact on the wage dynamics in the whole economy (Koczan, 2014). This was also one of key factors stimulating demand and high inflation and contributing to a sequence of currency crises between 2009 and 2014. The activist policy has been suspended after the latest episode of currency crisis in 2014 and Belarusian authorities sought to ensure a more market-based wage setting mechanism, which would preserve the link

\footnotetext{
11 The degree of exchange rate flexibility is also at the discretion of a central bank, i.e. it is a policy choice.
} 
between real wages and productivity.

More recently, in 2017, the discussion about nominal wage objectives has been reopened within the Belarusian government once again. Considering that, we include wages in our model to study the impact of nominal wage shocks on macroeconomic dynamics - domestic demand and price pressures - and response of monetary authorities to that.

\section{Fiscal support and directed lending}

The Belarusian government has been traditionally providing significant fiscal and quasi-fiscal support to SOEs. This support comes in various forms and includes: (i) fiscal expenditures, including export subsidies (ii) subsidized (directed) lending, (iii) debt guaranties and (iv) restructuring of SOEs debt to banks. Comprehensive accounting of quasi-fiscal activities appears challenging, including due to lack of time series capturing some forms of support. Also, while debt guaranties and debt restructuring add to fiscal risks and to potential pressures on public finances in the future, they seem to have no clear stimulating effect on aggregate demand in the short-run $^{12}$. In contrast, subsidized direct lending means providing extra financial resources to the economy by the banking system and hence it affects aggregate demand in the short-run ${ }^{13}{ }^{14}$.

\footnotetext{
${ }^{12}$ For example, debt restructuring involves swapping banks' loans to SOE's for budget loans, which is accompanied by issuing government bonds of equivalent amount and transferring them to banks. As a result, the initial debt of SOEs' to banking sector is replaced by IOU of the government vis-à-vis banks and of SOEs vis-à-vis government. In this scheme, no additional financial resources are spent and therefore there is no direct simulative effect on demand. Some effect might however come through the risk premium channel: as the stock of the government debt increases, investors might require higher premium to purchase such debt. This potentially might increase risk premium with higher level of the equilibrium (neutral) interest rate and hence slower economic growth in the long-run. We however do not analyze this long-run effects as it would require richer model of the fiscal sector, debt dynamics and more detailed modelling of the behavior of output in the long-run.

${ }^{13}$ Directed loans are provided in domestic and foreign currency, therefore we apply valuation adjustment to avoid counting change in the stock due to exchange rate movements as an extra impulse to aggregate demand.

${ }^{14} \mathrm{We}$ calculate directed lending based on the operational information that the NBRB provides to the IMF country team for Belarus. This includes lending under government programs and activities by banks and OJSC

"Development Bank of the Republic of Belarus" under the decisions of the President and the Council of Ministers of the Republic of Belarus. The information on lending under government programs and activities should not be considered statistical data and is presented for analytical purposes only. The list of government programs for which the NBRB conducts the analysis of lending is not complete. Authors are grateful to the IMF country team for Belarus for providing necessary data to clarify the coverage and make the valuation adjustment.
} 
Figure 3: Fiscal Support and Directed Lending, percent of GDP

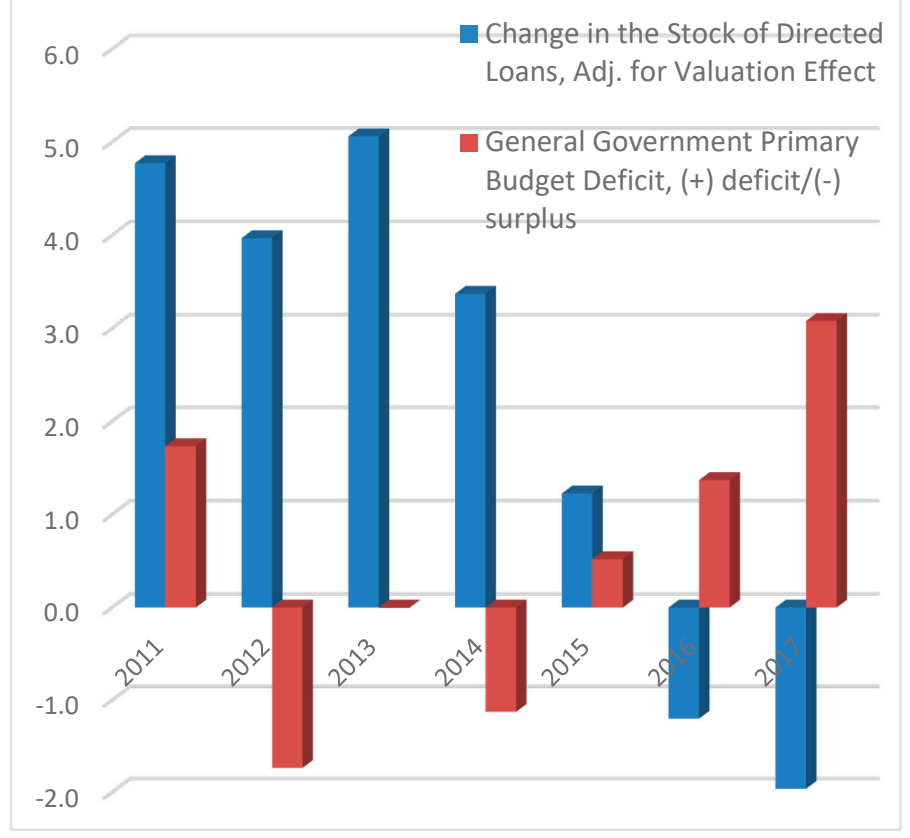

Source: WEO database and author's calculations
Subsidized lending has been particularly strong during the 2000s, and together with strong growth in nominal wages, contributed to macroeconomic imbalances and currency crises. Since 2015, the government has been cutting directed lending and plans to reduce the outstanding stock of such loans further (Figure 3).

We incorporate fiscal support and the directed lending in the QPM for Belarus to study pressures on aggregate demand and implications for monetary policy. The impact of fiscal stimulus on demand is commonly evaluated in the

form of fiscal impulse, which is the change of the cyclically-adjusted deficit between two periods. We assume that both fiscal policy and directed lending have similar impact on demand and calculate an impulse variable, which summarizes both. We take the ratio of fiscal deficit and of the change in the stock of directed loans to GDP. Then the change of this ratio between two consecutive quarters is an impulse variable that affects aggregate demand.

\section{E. Trade links with Russia and European Union}

Belarus is a small open economy with two major trading partners - Russian Federation and European Union - which account for almost three quarters of trade. The share of exports and imports of goods to GDP stands at 65 percent each. Economic and financial linkages have been particularly strong with Russia, which is reflected in a substantial harmonization of business cycles in these two economies (Figure 4). Belarusian exports of goods and services to this country are about 40 percent of total exports, while imports are approximately 60 percent. Furthermore, capital inflows from the eastern trading partners are significant: for example, about 60 percent of all FDIs come from Russia. The energy discounts and implicit subsidies that Russia provided to Belarus during in 2009-2015 are estimated at about 10 percent of Belarus GDP per year on average. 
Such economic links make Belarus demand and inflation exposed to economic developments in trading partners. Hence, we reflect such links in the model, to capture the effect of foreign developments on domestic macroeconomic dynamics and policy.

Figure 4: Economic growth in Belarus and Russia, $\mathrm{y}-\mathrm{o}-\mathrm{y}$, percent

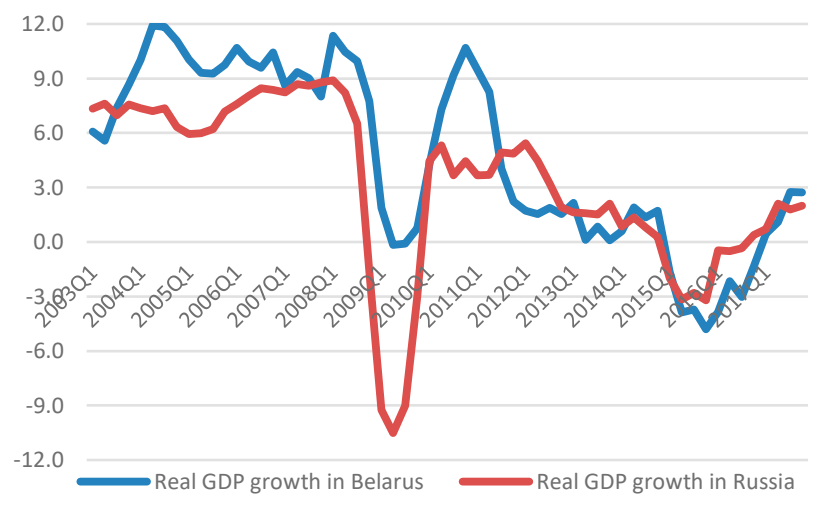

Source: NBRB data and author's calculations

A simpler setup of the canonical QPM suggests that only one largest trading partner represents the foreign sector, which may lead to omitting important information when trade and financial flows are diversified. In what follows we extend the canonical setup by allowing for three trading partners: Russia, EU and the US, with the latter being a proxy for the rest of the world.

\section{F. Regulated Prices}

Prices for some goods and services in the consumer basket are subject to administrative regulations. In particular, utility prices and transport tariffs are set by the government. Authorities report core and non-core inflation; prices for core goods and services are less volatile and driven by market-based setting mechanism. They account for circa 75 percent of the CPI basket. The more volatile non-core component - remaining part of the basket - includes prices for fruit and vegetable as well as regulated prices. Over the last 15 years the non-core prices clearly grew faster relative to core (Figure 5).

Figure 5.A: Core and non-core inflation, annualized qo-q, percent

Figure 5.B: Core and non-core prices, natural $\log * 100$
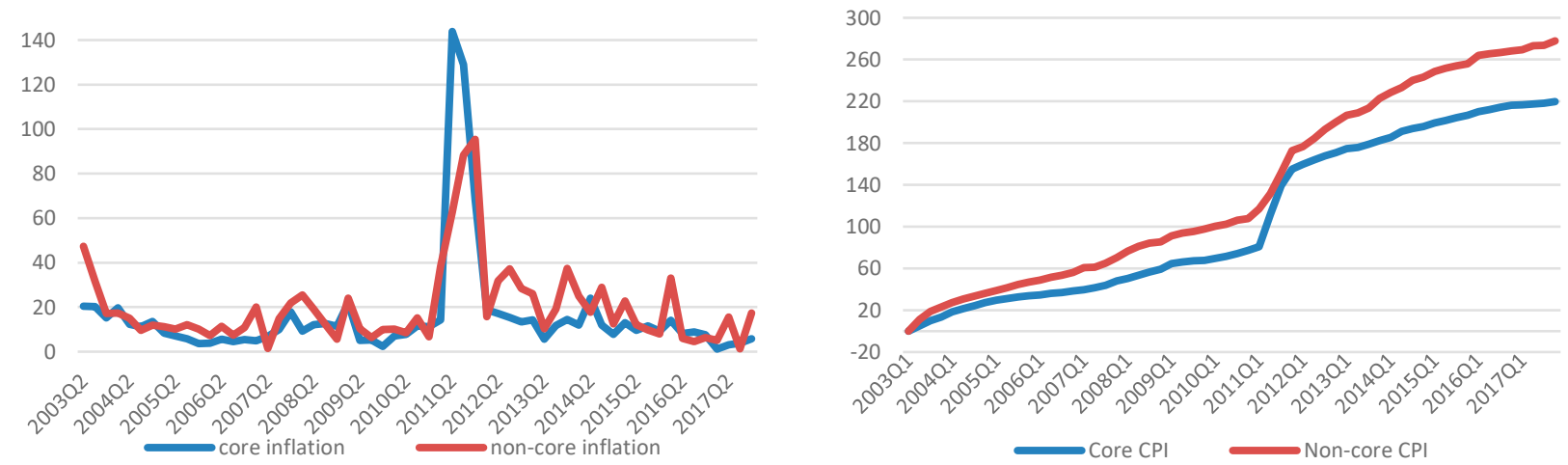

Source: NBRB and authors' calculations 
Authorities announced a plan to raise the utility cost recovery from 58 percent in 2017 to 100 percent over the next few years, which will imply a set of shocks to non-core inflation component in the future and continue the trend of non-core prices growing faster than the core. Given their different patterns of behavior and factors that push them, we model core and noncore prices as separate components in the supply block of the model.

\section{STRUCTURE AND FEATURES OF THE QPM FOR BELARUS}

This part describes how stylized facts alter representation of the QPM, otherwise described in Berg et al. (2006a) and Berg et al. (2006b). New equations or terms in equation different from the workhorse model are highlighted in red. The whole model is in Appendix B.

\section{A. Monetary policy and exchange rate framework}

The policy block in the model allows switching from the money targeting (MT) strategy with full adherence to the target, to partial MT adherence and to inflation targeting (IT). Regardless of the strategy, policy actions are reflected in the dynamics of money market interest rates, which is the first step in the policy transmission.

Hence, there are two implicit interest rates in the model, one for each "pure" policy regime: MT with full adherence to the target and IT. The policy interest rate consistent with inflation target, $i_{t}^{I T}$ is according to a forward-looking policy rule:

$$
i_{t}^{I T}=g_{1} \cdot i_{t-1}^{I T}+\left(1-g_{1}\right) \cdot\left(i_{t}^{\text {Neutral }}+g_{2} \cdot\left(E_{t} \pi 4_{t+3}-\pi 4_{t+3}^{\text {Tar }}\right)+g_{4} \cdot \hat{y}_{t}\right),
$$

where $E_{t} \pi 4_{t+3}$ is expected y-o-y inflation in time $t+3$ based on information at time $t, \pi 4^{T a r}$ is the inflation target, $\hat{y}$ is the output gap, and $i^{\text {Neutral }}$ is the neutral level of the policy interest rate consistent with expected inflation and economy operating at a potential output (i.e., the output gap is zero) ${ }^{15}$.

The second interest rate, $i^{M T}$, is consistent with the intermediate money target under monetary targeting strategy. Its level prevails in the money market if the central bank fully adheres to the money target. Money demand function relates money and the interest rates. The dynamic form of money demand in the model is the following:

$$
\Delta \mathrm{rm} 3_{t}=\Delta y_{t}+\gamma_{1}\left\{\left(i_{t}-i_{t}^{\text {Neutral }}\right)-\left(i_{t-1}-i_{t-1}^{\text {Neutral }}\right)\right\}+\gamma_{2} \overline{r m 3}_{t-1}-\Delta \bar{v}_{t}+\varepsilon_{t}^{\Delta \mathrm{rm} 3},
$$

\footnotetext{
${ }^{15}$ The neutral rate is defined as a sum of expected inflation and the natural rate of interest. The natural rate of interest is the real rate consistent with neutral effects on growth and inflation. Bezborodova and Vlcek (2018) provide an example of estimation of the natural rate for Belarus.
} 
where $\Delta \mathrm{rm} 3$ is real money growth, $\Delta y$ is real GDP growth, $\widehat{r m 3}$ is the real money gap, $\Delta \bar{v}$ is the rate of change in trend money velocity, and $\varepsilon^{\Delta \mathrm{rm} 3}$ is a money demand shock. Equation (2) ensures that the nominal money growth is consistent with the real growth adjusted by inflation and velocity. If the economy is in long-term equilibrium - and interest rate is at the neutral level and the real money demand gap is zero, (2) collapses to the identity from quantitative money theory: $\Delta \bar{m}_{t}-\pi 4_{t}^{T a r}=\Delta \bar{y}_{t}-\Delta \bar{v}_{t}$.

The real money gap ensures dynamic correction of variables in levels, so that demand for real money balances is in line with the level of output, $y_{t}$, adjusted by the velocity, $\bar{v}_{t}$, and the market interest rate, $i_{t}$ :

$$
\widehat{r m 3}_{t}=r m 3_{t}-\left(y_{t}-\gamma_{1}\left(i_{t}-i_{t}^{\text {Neutral }}\right)-\bar{v}_{t}\right) .
$$

When targeting money, the central bank sets the money growth target, $\Delta m 3^{\text {Tar }}$. Different designs of the money target can be explored in Andrle et al. (2013). In the model we reflect the design employed by the NBRB with the money target set one period in advance. The nominal money growth target is a sum of projected GDP growth, inflation target and shock to real demand for money, less the change in velocity at time $t$ as expected at time $t-1$ :

$$
\Delta m 3_{t}^{T a r}=E_{t-1}\left\{y_{t}^{G o v}\right\}+E_{t-1}\left\{\pi 4_{t}^{T A R}\right\}-E_{t-1}\left\{\Delta \bar{v}_{t}\right\}+E_{t-1}\left\{\varepsilon_{t}^{\Delta r m 3}\right\}
$$

The GDP projection $E_{t-1}\left\{y_{t}^{G o v}\right\}$ is produced by the Government and the NBRB takes it as exogenous when deciding the target for money growth. Setting the target in advance means defining it at $t-1$, before an actual shock to money demand, shocks to output and velocity are observed at $t$. Once these shocks take place, the central bank either does not accommodate the shocks by leaving money supply unchanged or accommodates them by fully adjusting the supply.

If the bank does not accommodate the shocks, then the original money target is met, but at the cost of a more volatile money market interest rate - the case of full adherence to money target.

The interest rate in the case of full adherence to money target $i_{t}^{M T}$ can be recovered from (2) where the left-hand side is replaced by the target and actual inflation and all shocks are accounted for ${ }^{16}$ :

$$
\begin{array}{r}
\Delta m 3_{t}^{\text {Tar }}-\pi_{t}=\Delta y_{t}+\gamma_{1}\left[\left(i_{t}^{M T}-i_{t}^{\text {Neutral }}\right)-\left(i_{t-1}-i_{t-1}^{\text {Neutral }}\right)\right]-\cdots \\
\ldots-\gamma_{2} \widehat{r m 3}_{t-1}-\Delta \bar{v}_{t}+\varepsilon_{t}^{\Delta r m 3},
\end{array}
$$

\footnotetext{
${ }^{16}$ Clearly, if there are no such shocks then $i_{t}^{M T}=i_{t}^{I T}$.
} 
hence, for $i_{t}^{M T}$ :

$$
\begin{aligned}
i_{t}^{M T}= & i_{t-1}+\left(i_{t}^{\text {Neutral }}-i_{t-1}^{\text {Neutral }}\right)+\cdots \\
& \ldots+\frac{1}{\gamma_{1}}\left\{\Delta m 3_{t}^{\text {Tar }}-\pi_{t}-\Delta y_{t}+\gamma_{2} \widehat{r m 3}_{t-1}+\Delta \bar{v}_{t}-\varepsilon_{t}^{\Delta \mathrm{r} m 3}\right\} .
\end{aligned}
$$

If the central bank accommodates shocks at least partially, the money market interest rate is smoothed at a cost of missing the money target in (4) - the case of only partial adherence to the money target. The market interest rate, $i_{t}$, is then an average of the IT and MT rates:

$$
i_{t}=m p r \cdot i_{t}^{I T}+(1-m p r) \cdot i_{t}^{M T}
$$

Hence, parameter $\mathrm{mpr}$ in the model allows capturing policy regimes ranging from "pure" money growth targeting with full adherence $(m p r=0)$ to the target, through the partial adherence $(0<m p r<1)$ to fully fledged inflation targeting $(m p r=1)$.

\section{Exchange rate}

Belarus gradually moves towards higher exchange rate flexibility. To account for that, the model allows for varying degrees of exchange rate flexibility by weighting two extreme regimes - free float and the exchange rate peg. The modified uncovered interest rate parity (UIP) condition in the model is similar to Benes et al. (2008) and it is the following:

$$
\begin{gathered}
s_{t}=(1-e p r) \cdot\left(s_{t-1}+\Delta s_{t}^{T a r}\right)+e p r \cdot\left(e_{1} \cdot\left(s_{t-1}+\Delta \bar{z}_{t}+\pi_{t}-\pi_{t}^{E X}\right)+\ldots\right. \\
\left.\ldots+\left(1-e_{1}\right) \cdot E_{t} s_{t+1}-\frac{i_{t}}{4}+\frac{i_{t}^{E X}}{4}+\frac{\text { prem }_{t}}{4}\right)+\varepsilon_{t}^{s},
\end{gathered}
$$

where $\Delta s^{T a r}$ is the implicit or explicit nominal exchange rate depreciation target, prem is the country risk premium, and $E_{t} s_{t+1}$ is the expected at time $t$ nominal exchange rate at $t+1$. By setting parameter $e p r=1$ one gets free floating exchange rate consistent with the common UIP with partly backward-looking agents. Any $0<e p r<1$ captures the case of exchange rate smoothing using FX interventions and epr $=0$ captures the case of a peg. Under the peg the central bank targets the rate of the nominal exchange rate depreciation, which should be consistent with the differential in inflation objectives and the rate of the long-run (equilibrium) real exchange rate depreciation, $\Delta \bar{z}$ :

$$
\Delta s_{t}^{T a r}=\Delta \bar{z}_{t}+\pi_{t}^{T a r}-\pi_{t}^{E X} .
$$

The more the central bank controls or smooths the exchange rate, the more difficult it is to steer the domestic money market rate unless capital controls are introduced. To capture the whole range of exchange rate and capital control policies, we introduce UIP implied interest rate, $i^{U I P}$. It is derived from the UIP equation and it is the interest rate which would prevail on the 
domestic money market if the central bank controls the nominal exchange rate ${ }^{17}$ and capital mobility is full:

$$
i_{t}^{U I P}=E_{t} \Delta s_{t+1}+i_{t}^{E X}+\text { prem }_{t}
$$

If we assume that the central bank loses its power to steer domestic interest rates, when it intervenes in the FX market, we can write the money market rate as a weighted average of the UIP implied rate and the IT rate:

$$
i_{t}=(1-e p r) \cdot i_{t}^{U I P}+e p r \cdot i_{t}^{I T} .
$$

Combining equation (10) and (6), we get a comprehensive set of monetary policy and exchange rate options and the dynamic equation for the interest rate:

$$
i_{t}=(1-e p r) \cdot i_{t}^{U I P}+e p r \cdot\left(m p r \cdot i_{t}^{I T}+(1-m p r) \cdot i_{t}^{M T}\right)+\varepsilon_{t}^{i} .
$$

The whole monetary and exchange rate policy block determining the policy interest rate and the exchange rate can be summarized by the previous equations. Table 1 lists calibration options and implied monetary and exchange rate regimes.

Table 1: Monetary policy and exchange rate regimes on the back of parameter setting

\begin{tabular}{|c|c|c|c|}
\hline & epr=0 & $0<e p r<1$ & epr $=1$ \\
\hline$m p r=0$ & $\begin{array}{c}\text { Money targeting and } \\
\text { pegged ER* }\end{array}$ & $\begin{array}{c}\text { Money targeting and } \\
\text { managed ER }\end{array}$ & $\begin{array}{c}\text { Money targeting and } \\
\text { floating ER }\end{array}$ \\
\hline$m p r=1$ & $\begin{array}{c}\text { Inflation targeting and } \\
\text { pegged ER* }\end{array}$ & $\begin{array}{c}\text { Inflation targeting and } \\
\text { managed ER }\end{array}$ & $\begin{array}{c}\text { Inflation targeting and } \\
\text { floating ER }\end{array}$ \\
\hline
\end{tabular}

Note: * - assumes full capital controls or the peg consistent with the money growth or inflation objective.

Hence, equations (1)-(5'), (7)-(8) and (11) layout the monetary and exchange rate model block.

\section{B. Dollarization}

Due to dollarization, the real monetary condition index ( $r m c i)$ is modified by adding the effective real interest rate on FX denominated loans:

$$
r m c i_{t}=b_{21} \cdot\left(b_{22} \cdot \hat{r}_{t}+\left(1-b_{22}\right) \cdot \hat{r}_{t}^{F X}\right)+\left(1-b_{21}\right) \cdot \hat{z}_{t}
$$

\footnotetext{
17 The exchange rate can be controlled using unsterilized interventions or by setting the domestic interest rate. If the exchange rate path is achieved using the market interest rate then the UIP implied rate equals to the market one.
} 
where $\hat{r}$ is the gap of the domestic real policy interest rate, $\hat{r}^{F X}$ is the gap of the real effective rate for on FX loans. ${ }^{18}$ The real rate on FX loans is derived from the nominal cost of servicing the FX loans, $i^{F X}$. This nominal cost is equal to the nominal interest rate on a loan adjusted by the expected nominal exchange rate depreciation:

$$
i_{t}^{F X}=i_{t}^{\widetilde{E F}}+\Delta s_{t+1}^{\widetilde{E F}}+\operatorname{prem}_{t}^{F X}
$$

where $i^{\widetilde{E F}}$ is the effective interest rate on FX loans provided by the Belarusian banks, $\Delta s^{\widetilde{E F}}$ is the expected rate of effective nominal exchange rate depreciation, and $\operatorname{prem}^{F X}$ is the credit premium. The interest rate on FX loans is a weighted average of foreign - EU, RU, and the US - rates. Tilde above variables indicates that the effective measures use the shares of EUR, RUB, and USD currencies in total FX loans as weights. These weights differ from the trade weights, which are used in the rest of the model (see appendix C). The credit premium is assumed to follow an AR process.

The equilibrium level of the FX lending rate, $\bar{r}^{F X}$, is the weighted average of the foreign equilibrium real interest rates, $\bar{r}_{t}^{\widetilde{E F}}$, adjusted by the equilibrium $\mathrm{FX}$ country risk premium, $\overline{\text { rrem }}^{F X}$, and equilibrium real exchange rate depreciation (FX loans weights), $\Delta \bar{z}^{\widetilde{E F}}$ :

$$
\bar{r}_{t}^{F X}=\bar{r}_{t}^{\widetilde{E F}}+\overline{p r e m}_{t}^{F X}+\Delta \bar{z}^{\widetilde{E F}}+\varepsilon_{t}^{\bar{r}^{F X}} .
$$

\section{Wages}

We assume sticky nominal wages to match the moments in the data and follow Erceg et al. (2000) to have the wage equation similar to the Phillips curve. The real wage gap, $\widehat{r w}$, and the output gap, $\hat{y}$, drive the nominal wage growth, $\Delta w$ :

$$
\Delta w_{t}=c_{1} \cdot \Delta w_{t-1}+\left(1-c_{1}\right) \cdot \Delta w_{t+1}+c_{2} \cdot\left(c_{3} \cdot \hat{y}_{t}-\left(1-c_{3}\right) \cdot \widehat{r w}_{t}\right)+\varepsilon_{t}^{w}
$$

According to (15), the wage growth speeds up during booms (positive output gap) and decelerates during busts (negative output gap). On the contrary, there is a negative correlation between the nominal wage growth and the real wage gap: e.g. real wages below the equilibrium level imply that the nominal wage growth should speed up. The real wage is the nominal wage adjusted by CPI, in log terms:

$$
r w_{t}=w_{t}-p_{t}
$$

\footnotetext{
${ }^{18}$ Example of dollarization derived in a DSGE model can be found in Djukic et al. (2018).
} 
The real wage is then decomposed into the unobserved gap $\widehat{r w}$ and the equilibrium $\overline{r w}$ components:

$$
r w_{t}=\widehat{r w}_{t}-\overline{r w}_{t}
$$

The share of nominal wages in nominal GDP is relatively stable. In the model we have real wages and real GDP, which are obtained by deflating nominal variables with two deflators: CPI and GDP deflator, respectively. Applying two different deflators gives rise to a trend in the ratio of real wages to real GDP due to a trend in CPI relative to GDP deflator ${ }^{19}$. We therefore link equilibrium level of real wages to the equilibrium level of real GDP and model a trend in the ratio of these two variables:

$$
\begin{gathered}
r w_{-} y_{t}=r w_{t}-y_{t}, \\
\Delta \overline{r w_{-} y_{t}}=\rho^{\bar{r} w_{-} y} \cdot \Delta \overline{r w_{-} y_{t-1}}+\left(1-\rho^{\overline{r w_{-} y}}\right) \cdot \Delta \overline{r w_{-} y_{S S}}+\varepsilon_{t}^{\overline{r w_{-} y}}
\end{gathered}
$$

The real wage gap enters also the output gap equation and the Philips curve for core inflation to capture that wages create demand and partly responsible for domestic cost pressures.

\section{Fiscal and Directed Lending Impulses}

We define fiscal and directed lending impulse variables, which approximate short-run demand pressures from respective policies and therefore enter the output gap equation. The budget deficit and change in directed loans in percent of nominal GDP are the following:

$$
\begin{gathered}
d l 2 n g d p_{t}=\frac{\Delta D L_{t}}{N G D P_{t}}, \\
b d 2 n g d p_{t}=\frac{B D_{t}}{N G D P_{t}},
\end{gathered}
$$

where $\triangle D L$ is the change in the stock of directed loans, $B D$ is a fiscal (budget) deficit of the consolidated government and NGDP is the level of nominal GDP. Then the first differences for these two variables are directed lending and fiscal impulses respectively. We treat them as extra policy (or control) variables and assume that they are both simple AR(1) processes in our model:

$$
\begin{aligned}
\Delta d l 2 n g d p_{t} & =\rho^{d l} \cdot \Delta d l 2 n g d p_{t-1}+\varepsilon_{t}^{d l 2 n g d p}, \\
\Delta b d 2 n g d p_{t} & =\rho^{b d} \cdot \Delta b d 2 n g d p_{t-1}+\varepsilon_{t}^{b d 2 n g d p} .
\end{aligned}
$$

\footnotetext{
${ }^{19}$ GDP deflator grew faster than CPI over the last 15 years. Another way to deal with this would be to explicitly introduce GDP deflator in the model and model trends in relative CPI and GDP deflator. However, we prefer a more parsimonious way, which lets us avoid modelling extra price indices.
} 
The total fiscal and directed lending impulse is then:

$$
f d l i m p_{t}=\Delta b d 2 n g d p_{t}+\Delta d l 2 n g d p_{t} .
$$

\section{E. Foreign block}

The high share of Russia and the EU in the Belarusian external trade requires using effective measures in the foreign block of the model. Effective inflation, the output gap, and the nominal interest rate are weighted averages of respective variables for Russia, the EU, and the US as a proxy for the rest of the world and have the following representation:

$$
x_{t}^{E X}=w^{R U} \cdot x_{t}^{R U}+w^{E U} \cdot x_{t}^{E U}+\left(1-w^{R U}-w^{E U}\right) \cdot x_{t}^{U S},
$$

where $w^{\prime} s$ are the weights and $x^{\prime} s$ are inflation, the output gap, or the interest rates for each country. ${ }^{20}$ All effective foreign variables have superscript $E X$. The weights are consistent with the country shares in external trade and FDI inflows.

Each foreign country block admits a non-structural, i.e. a reduced form, representation: variables follow AR processes with calibrated steady-states. For example, the "Russian" block:

$$
\begin{gathered}
\pi_{t}^{R U}=\rho^{\pi R U} \cdot \pi_{t-1}^{R U}+\left(1-\rho^{\pi R U}\right) \cdot \pi^{R U}{ }^{S S}+\varepsilon_{t}^{\pi^{R U}}, \\
\hat{y}_{t}^{R U}=\rho^{\hat{y}^{R U}} \cdot \hat{y}_{t-1}+\varepsilon_{t}^{\hat{y}^{R U}}, \\
i_{t}^{R U}=\rho^{i^{R U}} \cdot i_{t-1}^{R U}+\left(1-\rho^{i^{R U}}\right) \cdot\left(\bar{r}^{R U}+\pi^{R U^{S S}}\right)+\varepsilon_{t}^{i^{R U}},
\end{gathered}
$$

where $\pi$ is q-o-q inflation, $\hat{y}$ is the output gap, $i$ are the nominal policy rate, $\bar{r}$ is the real equilibrium interest rate and $\varepsilon$ 's are shocks.

The foreign block in this representation requires (i) using the effective nominal exchange rate and (ii) producing or collecting extraneous forecasts for all trading partners in the model. Accordingly, the effective nominal exchange rate is present in the model and it is used in (7) as well as in the definition of the real exchange rate. Given the effective measures, forecasting with the model requires collecting forecasts for Russia, the EU block of countries, and the US. Therefore, there is a trade-off expanding the model further by adding more countries or regions.

\footnotetext{
${ }^{20}$ The effective foreign demand is approximated using only RU and the EU output gaps. The US variables are present in effective inflation and interest rate measures only.
} 


\section{F. Inflation block}

Core and non-core inflation differ in their dynamics and composition of the real marginal costs. $^{21}$

\section{Core inflation}

$$
\begin{array}{r}
\pi_{t}^{C}=a_{11} \cdot E_{t} \pi_{t+1}^{C}+\left(1-a_{11}\right) \cdot \pi_{t-1}^{C}+a_{12} \cdot\left\{a_{13} \cdot\left[a_{14} \cdot \hat{y}_{t}+\left(1-a_{14}\right) \cdot \widehat{r w}_{t}\right]+\ldots\right. \\
\left.\ldots+\left(1-a_{13}\right) \cdot\left[\left(1-a_{15}\right) \cdot\left(\hat{z}_{t}-\widehat{r p}_{t}\right)+a_{15} \cdot\left(\widehat{r p}_{t}^{\text {Oil }}-\widehat{r p}_{t}\right)\right]\right\}+\varepsilon_{t}^{\pi^{C}},
\end{array}
$$

where $\pi^{C}$ is core inflation, $\hat{y}$ is the output gap, $\hat{z}$ is the real effective exchange rate gap and $\widehat{r w}$ is the gap of the real wage. According to that, agents' inflation expectations is a weighted average of past inflation $\pi_{t-1}^{C}$, and inflation expected in the next period $E_{t} \pi_{t+1}^{C}$ Relative prices of core and headline CPI is the difference in respective logs:

$$
r p_{t}=p_{t}^{c}-p_{t}
$$

and the respective gap, $\widehat{r p}$, is:

$$
\widehat{r p}_{t}=r p_{t}-\overline{r p}_{t}
$$

The relative price of oil is ${ }^{22}$

$$
r p_{t}^{o i l}=p_{t}^{o i l}-\left\{w^{R U} \cdot c p i_{t}^{R U}+w^{E U} \cdot c p i_{t}^{E U}+\left(1-w^{R U}-w^{E U}\right) \cdot c p i_{t}^{U S}\right\}
$$

with the respective oil price gap

$$
\widehat{r p}_{t}^{o i l}=r p_{t}^{o i l}-\overline{r p}_{t}^{\text {oil }}
$$

The composition of real marginal costs differs from that in the canonical model. We split them into domestic and imported costs, and imported costs are further decomposed into energy and non-energy components. The real exchange rate gap approximates prices of non-energy imports and ensures that the price level in Belarus and foreign economies is in line with the relative version of purchasing power parity. This gap is further adjusted by the relative price gap to ensure constant relative price levels, which essentially gives the real exchange rate gap defined using core CPI. The relative price of oil approximates the cost of imported energy. Domestic

\footnotetext{
${ }^{21}$ Also, see Andrle et al. (2013b)

${ }^{22}$ Note that the price of oil is in units of the basket of three currencies RUB, EUR and USD taken with the weights as in (23).
} 
costs are defined as a combination of the real wage gap, approximating the cost of labor, and the output gap, approximating all other domestic costs.

Because the non-core component in large encompasses utilities and transportation costs we assume that the price setting for this component primarily depends on the domestic equivalent of imported costs. Hence, the Philips Curve for non-core inflation is the following:

$$
\begin{array}{r}
\pi_{t}^{N C}=a_{21} \cdot E_{t} \pi_{t+1}^{N C}+\left(1-a_{21}\right) \cdot \pi_{t-1}^{N C}+a_{22} \cdot\left\{a_{23}\left(\widehat{r p}_{t}^{O i l}+\hat{z}_{t}+\frac{w^{C}}{1-w^{C}} \cdot \widehat{r p}_{t}\right)+\cdots\right. \\
\left.\ldots+\left(1-a_{23}\right) \cdot\left(\hat{z}_{t}+\frac{w^{C}}{1-w^{C}} \cdot \widehat{r p}_{t}\right)\right\}+\varepsilon_{t}^{\pi^{N C}} .
\end{array}
$$

\section{G. Linking pieces together in the demand block}

The demand block features of the output gap equation

$$
\hat{y}_{t}=b_{1} \cdot E_{t} \hat{y}_{t+1}+b_{2} \cdot \hat{y}_{t-1}-b_{3} \cdot r m c i_{t-1}+b_{4} \cdot \hat{y}^{E X}+b_{5} \cdot f d l i m p_{t}+b_{6} \cdot \widehat{r w}_{t-1}+\varepsilon_{t}^{\hat{y}}
$$

and the definition of real monetary conditions index (13). This equation includes the real wage gap as in (17), the sum of two impulses (21) and the effective output gap term defined according to (22). Thus, the demand block completes the description of the key building blocks of the QPM for Belarus.

\section{Model Calibration and Properties}

The model is calibrated to reflect stylized facts of the Belarus economy and capture the monetary policy transmission mechanism. Calibrating model parameters is an iterative process. We identify several groups of parameters. The first is the set that determines the model steady state. These parameters can be calibrated using historical averages and policy objectives, for example, the inflation target. The second group are coefficients which affect dynamic properties of the model. This group includes coefficients in structural equations and in equations which do not have structural representation, the latter for example, are relationships for changes in longterm trends. The literature, other published models and data provide guidance on values of parameters in structural equations. The parameters in non-structural equations are calibrated to match the observed data and ensure reasonably smooth trends. Finally, the third group of parameters consists of standard deviations of shocks, which are calibrated to match the observed variance in the data. Calibration checks and test are presented in the next chapter. ${ }^{23}$

\footnotetext{
${ }^{23}$ Calibrated values of steady-state parameters and coefficients in structural equations are in Annex B. We provide remaining parameters, including standard deviation of shocks upon request.
} 
When calibrating the model, we primarily focus on matching the data and the monetary policy and the exchange rate regime after 2014. At that point the NBRB officially switched to a managed exchange rate and operated under the money targeting policy strategy. ${ }^{24}$ Prior to 2015 the exchange rate regime was classified as a peg with horizontal bands and the nominal exchange rate served as a policy anchor.

Impulse responses of the model to structural shocks differ from that of the canonical model because of differences in transmission mechanisms. We show responses to nominal exchange rate depreciation to illustrate how the interplay of dollarization and nominal exchange rate rigidity affects transmission. For that we run our model twice: with the degree of dollarization as is present in the economy and assuming no dollarization. Further, we compare responses to a money demand shock and a common demand shock (shock to the output gap) under the current regime and under a pure inflation targeting, i.e. parameter $m p r=1$. The Belarusian economy is also hit by other shocks, for example supply, foreign shocks, etc., however, we leave analysis of those beyond the scope of this paper.

The pass-through of nominal exchange rate depreciation to real economic activity is altered by dollarization (Figure 6). Impulse responses to nominal depreciation under the baseline (Belarus) calibration and the artificial case of no dollarization are respectively solid and dashed lines. ${ }^{25}$ In both cases, the nominal depreciation creates inflationary pressures directly through higher import prices as well as through an indirect exchange rate channel stimulating demand and the output. The economy in each setup expands initially due to accommodative aggregate real monetary conditions, because the undervalued exchange rate outweighs higher real cost of borrowing. Once the positive interest rate differential reverses and the nominal exchange rate starts to appreciate, the aggregate monetary conditions tighten. Due to that inflation returns back to the target as demand moderates, and costs of imports decline on the back of strengthening domestic currency.

The differences between the cases with and without dollarization are visible in the dynamics of real monetary conditions and the output gap. In the "dollarization" case, we observe the interplay of dollarization and rigidity in the nominal exchange rate, according to the current exchange rate regime. The nominal depreciation in the first period creates expectations higher expected costs of borrowing in FX, which in the "dollarization" case makes aggregate monetary conditions tighter than that in "no dollarization" case. As a result, dollarization reduces the extent of accommodative

\footnotetext{
${ }^{24}$ It is also reflected in the IMF's AREAR classification.

${ }^{25}$ We use an unexpected shock to the country risk premium. The shock is persistent and calibrated to depreciate the nominal exchange rate by about 10 percent over the first year of simulation.
} 
aggregate monetary conditions and initial stimulating effect of nominal depreciation shock on output. Hence, the dollarization modifies the transmission mechanism.

Figure 6: Nominal exchange rate depreciation shock
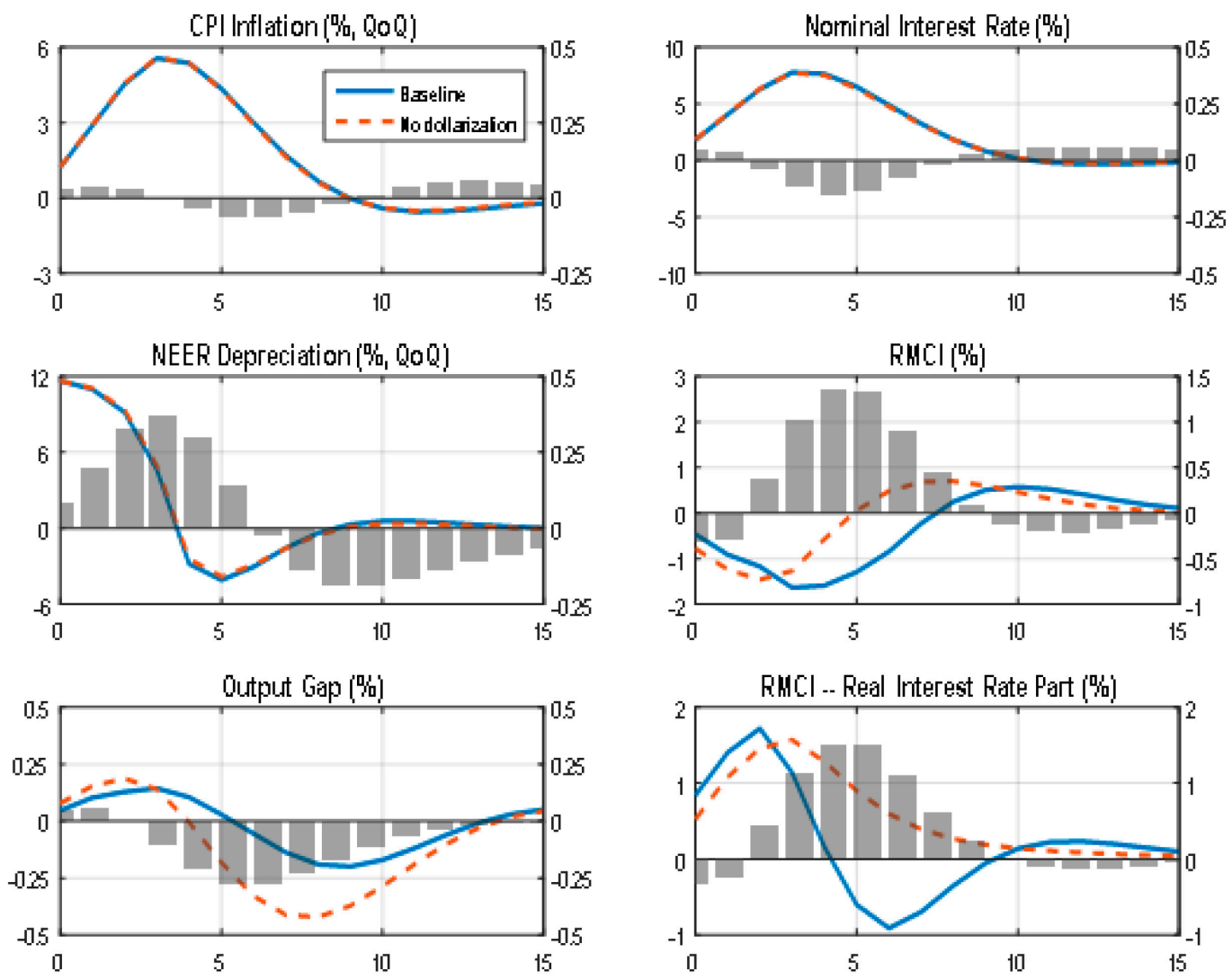

Source: Authors' calculations

Note: Each plot shows impulse response of a variable with solid (baseline) and dashed (no dollarization) lines referring to the left vertical axis. Gray bars reflect the difference in percentage points between the impulse responses: the trajectory given by the dotted less the one by the solid line. The bars are measured against the right vertical axis.

Dollarization also leads to additional costs in terms of initially higher inflation when the economy is exposed to an aggregate demand shock. The demand shock elevates activity and inflation and hence the central bank should react by tightening (increasing the nominal interest rate) which in turn leads to currency appreciation (Figure 7). Both, higher cost of borrowing and stronger currency, eventually make aggregate monetary conditions tighter and cool economy. In "dollarization" case, however, the initial exchange rate appreciation implies lower the expected cost of borrowing in foreign currency. This makes aggregate monetary conditions less restrictive and demand and inflation relatively higher in "dollarization" case than that in "no dollarization". The central bank in "dollarization" case should also increase the nominal interest rate relatively more to restore equilibrium. 
Figure 7: Demand shock
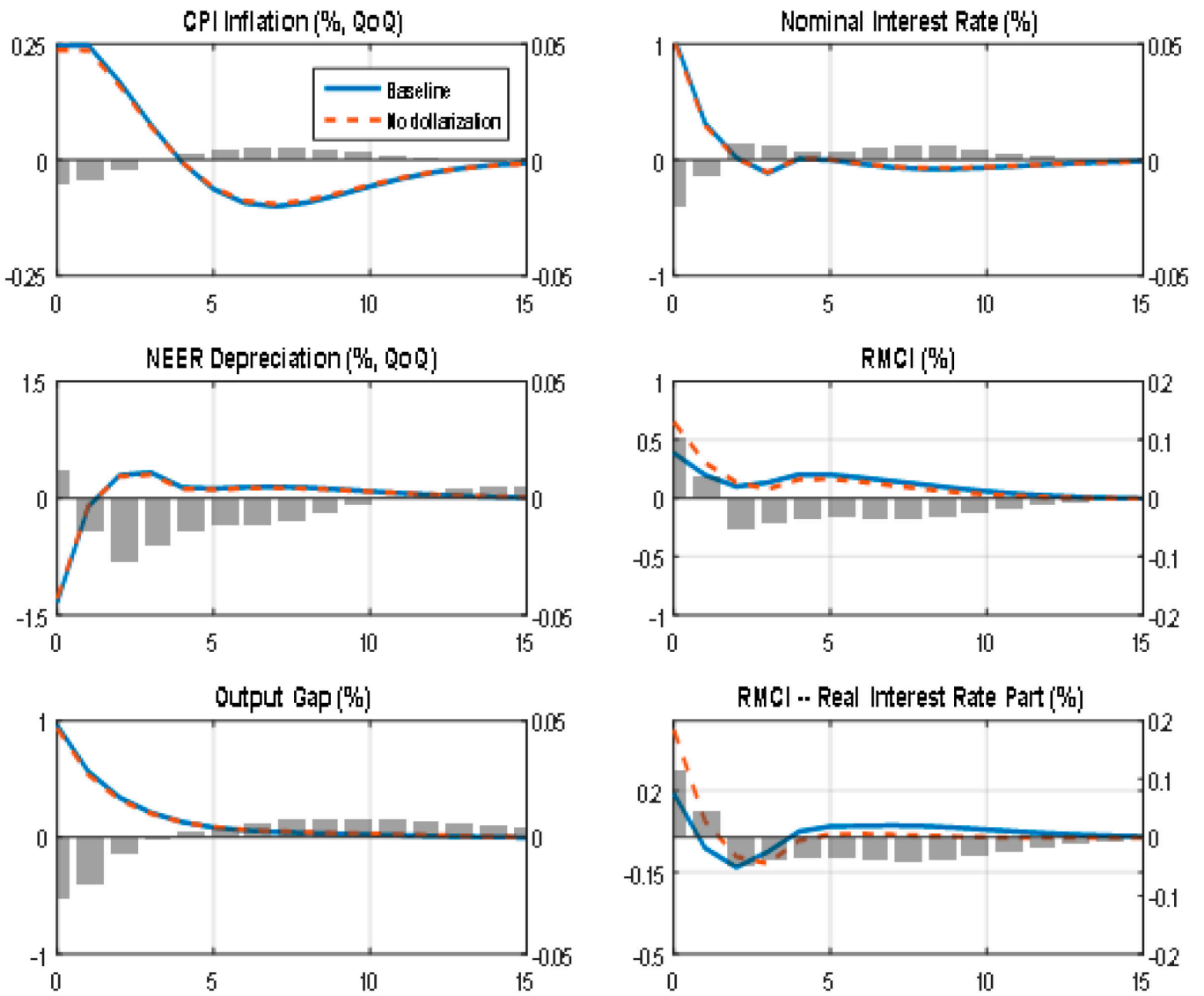

Source: Authors' calculations

Money demand shocks pose challenge to money targeting, which is the current monetary policy regime. Figure 8 shows impulse responses to an unexpected drop of money demand by 1 percent under the current money targeting (solid lines) and under IT regime (dashed line). This shock is not fully accommodated via reducing money supply to the same extent, because under the money targeting regime the central bank partially adheres to the money supply growth target. As a result, money market interest rate declines and induces accommodative monetary conditions. Given the negative interest rate differential, the nominal exchange rate depreciates. Accommodative conditions in both parts - real interest rates and the real exchange rate stimulate domestic demand and economy operates above potential (positive output gap). Hence, the partial adherence to the money growth target in a situation of a money demand shock causes economic volatility, i.e. demand and inflationary pressures emerge. 
Figure 8: Money demand shock
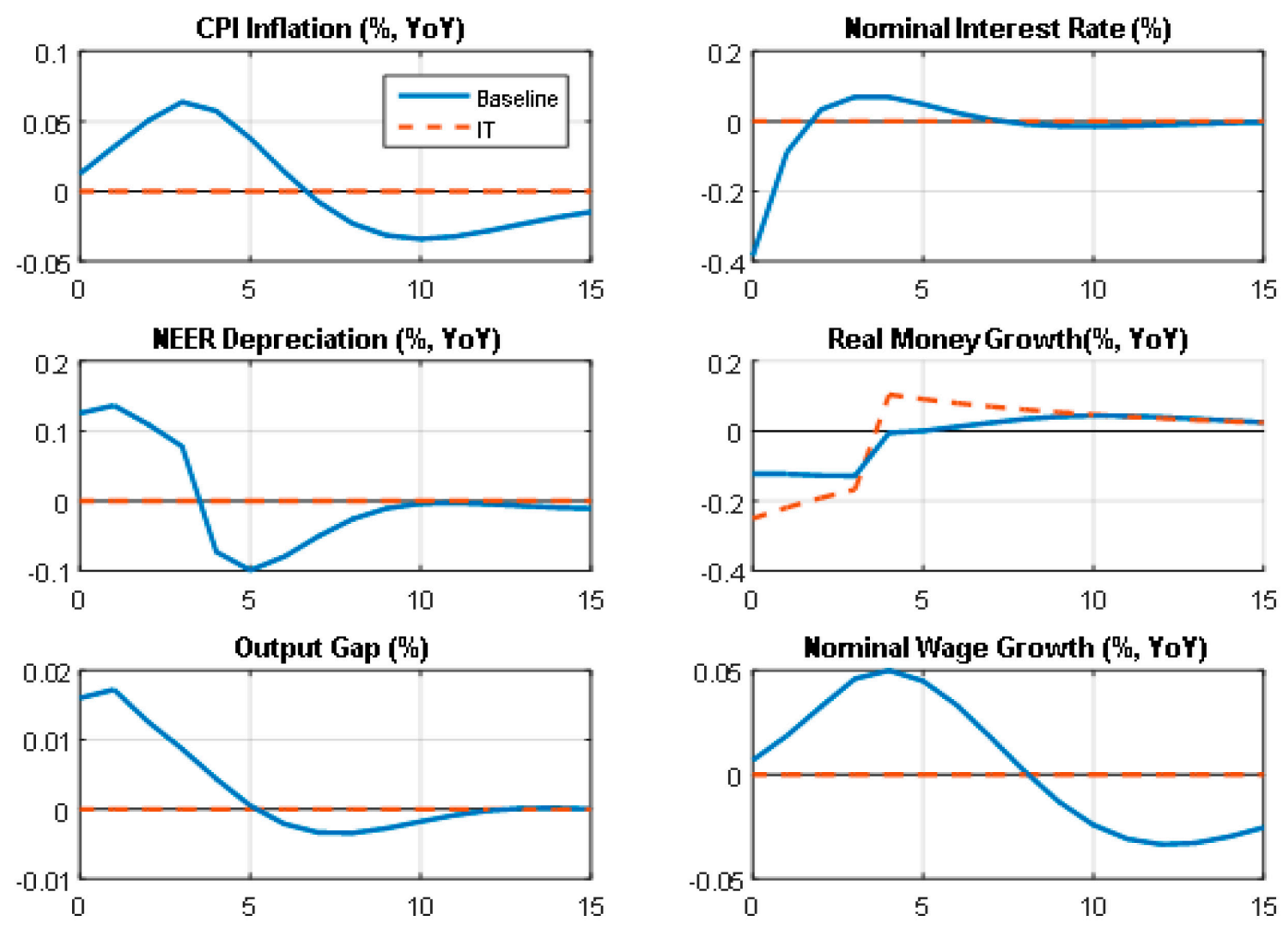

Source: Authors' calculations

On the contrary, under the inflation targeting regime, a central bank would use the money market interest rate as an operational objective and adjust money supply to keep this rate unchanged. As a result, real money growth would decline in response to money demand shock and higher volatility in money supply would be traded for no additional volatility in inflation and output.

Being on the interbank market daily, the central bank faces issues with identifying and responding to other possible underlying shocks that induce shifts in demand for reserve money. The optimal response to the money demand shock is to accommodate the shock to large extend if not fully. However, if the underlying shock which raises demand for reserve money is the output gap shock, the central bank should tighten and thus the shock should not be accommodated. The issue is that the central bank is not able to identify the type of the underlying shock only observing demand for reserve money. Observations of inflation and real economic activity are needed to identify the shock, but this information is not available daily and comes with a significant delay. Therefore, when targeting money supply, it appears difficult for a central bank to distinguish these shocks under money targeting and act on the money market by accordingly changing money supply on a daily basis. Therefore, and also recognizing 
endogeneity of the money creation, central banks in advanced economies transit to the interestrate-based policy and mostly abandon money targeting as the policy strategy.

\section{MODEL SIMULATIONS AND HISTORICAL DATA INTERPRETATION}

The calibration of the model is verified using several simulation exercises. First, in-sample simulations are used to check the ex-post forecasting power of the model. Second, we conduct filtration of the historical data. Finally, the filtration is used to decompose observed variables into structural shocks.

\section{In-sample forecast}

In-sample model-based forecasts compared with the actual data. If model forecasts do not deviate from the data systematically, we consider the model and its calibration as explaining the data well. We assume that all exogenous variables in the model are known over the forecasting horizon. All other observed variables are known only until the starting date of the forecasting simulation. No expert judgments are incorporated when the forecasts are produced.

We calculate the ratios of RMSFEs for our model and the random walk (RW) benchmark to compare forecasting performance for forecasting horizons from 1 to 8 quarters (Table 1).

Table 1: In-sample forecasting performance of the QPM vis-à-vis Random Walk (RW) benchmark during 1Q 2004 - 1Q 2017

\begin{tabular}{|l|c|c|c|c|c|c|c|c|}
\hline \multirow{2}{*}{\multicolumn{1}{c|}{ Variable }} & \multicolumn{7}{|c|}{$\begin{array}{c}\text { The ratio of RMSEs for QPM over RW, } \\
\text { for the forecast horizon quarters ahead }\end{array}$} \\
\cline { 2 - 11 } & $\mathbf{1 Q}$ & $\mathbf{2 Q}$ & $\mathbf{3 Q}$ & $\mathbf{4 Q}$ & $\mathbf{5 Q}$ & $\mathbf{6 Q}$ & $\mathbf{7 Q}$ & $\mathbf{8 Q}$ \\
\hline Real GDP Growth, percent YoY & 0.39 & 0.39 & 0.38 & 0.37 & 0.35 & 0.31 & 0.33 & 0.38 \\
\hline Headline CPI Inflation, percent YoY & 0.53 & 0.62 & 0.68 & 0.73 & 0.71 & 0.70 & 0.69 & 0.68 \\
\hline Nominal Interest Rate, percent p.a. & 0.89 & 0.77 & 0.85 & 0.81 & 0.77 & 0.80 & 0.85 & 0.92 \\
\hline $\begin{array}{l}\text { Nominal Effective Exchange Rate } \\
\text { Depreciation, percent YoY }\end{array}$ & 0.74 & 0.69 & 0.67 & 0.68 & 0.67 & 0.71 & 0.74 & 0.75 \\
\hline Real money growth, percent YoY & 0.61 & 0.60 & 0.53 & 0.47 & 0.38 & 0.39 & 0.47 & 0.55 \\
\hline Nominal Wage Growth, percent YoY & 0.37 & 0.42 & 0.49 & 0.58 & 0.64 & 0.66 & 0.64 & 0.61 \\
\hline
\end{tabular}

Source: Authors' calculations.

The performance of the QPM is better for all the variables over all quarters, especially for real GDP growth. Significantly better forecasting power of the QPM compared to the random walk model is visible for wage growth. Real money growth performance is improving towards the six quarters period. The QPM performance for CPI inflation, the interest rate and nominal 
depreciation is adversely affected by the crisis period and by the changes monetary policy strategy, but the QPM still outperform the RW model.

Figure 9 presents in-sample simulations where the dotted lines are model based forecasts 8quarters ahead and the solid black line is the actual data. We do not consider the change in the exchange rate and monetary policy regime over the history, keeping the calibration of both regimes as in the period after $2014 .{ }^{26}$

Figure 9: QPM-based In-sample forecasts for main macroeconomic variables
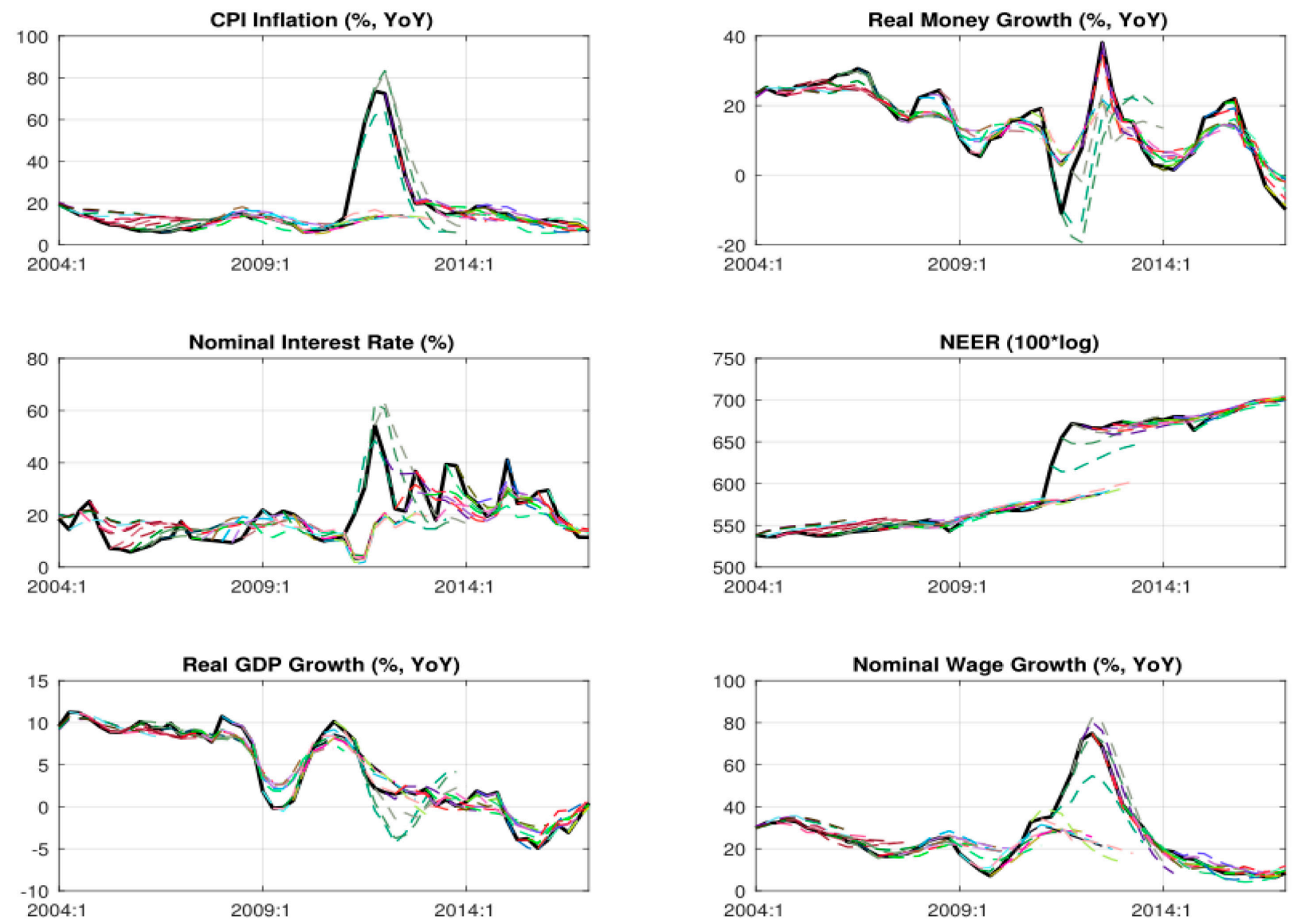

Source: Authors' computations

Note: The in-sample forecasts starting in a particular time point are depicted by different colors and consistent across all presented variables.

Model-based forecasts after 2014, i.e. during the period of money targeting and the managed exchange rate, match the actual data reasonably well. However, the model does not project such a considerable slowdown of the economy in 2015 and 2016 which was related at least partly to

\footnotetext{
${ }^{26}$ Taking the change of the regime into account in the in-sample simulations should further improve the performance of the simulation.
} 
structural problems of the economy. ${ }^{27}$ In line with lower deceleration of the real growth, the model predicts a slightly faster nominal wage growth.

Despite a different exchange and monetary policy regime, the model forecasts replicate the actual data well also before the exchange rate crisis in $2011 .{ }^{28}$ Forecasts of the real growth and exchange rate follow the actual data closely, indicating appropriate calibration of the model. On the contrary, the predicted inflation is often higher than the actual one.

The model is not able to fully predict the exchange rate crisis in 2011 and substantial exchange rate realignment, and the subsequent exchange rate stabilization that followed. Factors beyond the business cycle were driving this crisis. They included widening current account deficits coupled with quickly depleting foreign exchange reserves of the central bank, and neither of these factors is explicitly present in the model. Given the nature of the crisis, the forecasts of all variables - the exchange rate and inflation in particular - undershot the actual data. On the contrary, persistency of key variables during usual non-crisis times results in forecasts of inflation and wage growth that overshoot actual data after the crisis. As a result, during this period the model also suggests higher domestic interest rate and, consistent with that, lower rate of money growth and a stronger domestic currency.

\section{Historical data filtration}

We apply Kalman filtration (KF) technique to match the actual data by the model and to estimate unobserved variables including structural shocks. The technique is well known and (see Benes et al. (2010), for example), and we focus on two practical issues related to data filtration on the historical sample. First, we allow for time variation of standard deviations (stds) of shocks to match the data as this should help to better account for the exchange rate crisis in 2011. We let the stds of shocks to the nominal effective exchange rate, to core and non-core inflation, and to the nominal interest rates be higher i.e. between the second quarter 2011 to the first quarter 2012 than the stds of the same shocks in the rest of the sample. Second, the model structure and KF let us estimate the underlying unobserved interest rates consistent with the inflation targeting policy strategy $\left(i^{I T}\right)$ and the money targeting strategy with full adherence to the money growth target $\left(i^{M T}\right)$ and compare them with the observed money market rate.

\footnotetext{
${ }^{27}$ Forecasts of a more depreciated nominal exchange rate also contribute to overshooting the actual data for real GDP growth in in-sample simulations.

${ }^{28}$ Factors behind the exchange rate crises in Belarus are discussed in Miksjuk et. al (2015).
} 
Allowing for time-varying stds is crucial for informing the KF estimates of unobserved variables and of the output gap, in particular. We need to ensure that all gaps in the model follow their definition as the inflationary part of a variable. Therefore, there must be a strong link between gaps and inflation. For the GDP gap this can be ensured only if the standard deviation of the cost push shock in equations for core inflation is not too high and therefore information from inflation feeds into the estimate of an unobserved GDP gap, rather than to the estimate of the cost push shock.

Figure 10: The output gap estimates with constant and time-varying standard deviations of shocks in the model

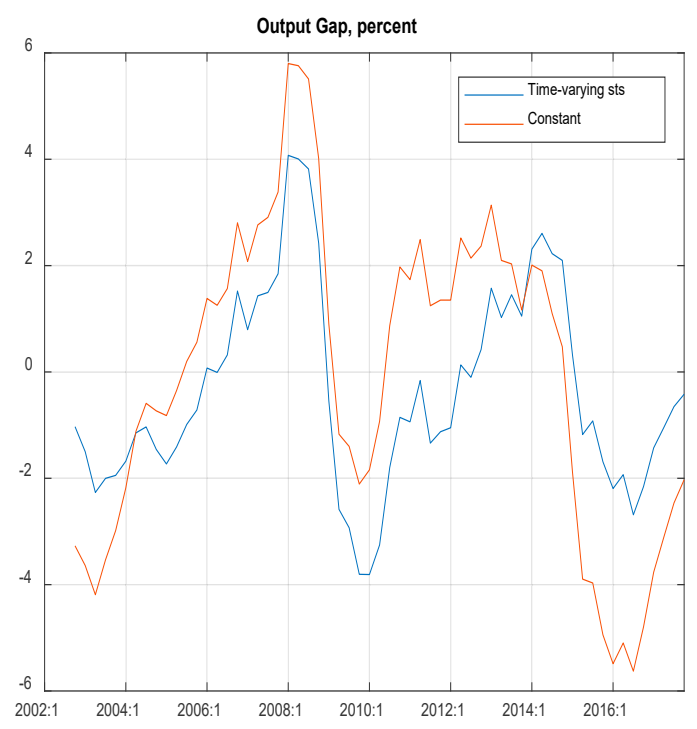

Source: Authors' calculations
However, the 2011 currency crisis and the subsequent hike in inflation are not fully explained by the business cycle dynamics. Hence, preserving constant stds over the whole sample may potentially distort the estimate of the unobserved GDP gap. ${ }^{29}$ To solve this issue, we apply time varying stds, which are higher during the crisis and meaningfully lower in normal times. The estimates of the GDP gap for constant and time-varying stds differ (Figure 10). When time variation is allowed and higher stds are take place during the crisis of 2011, the link between the output gap and inflation is relaxed and the gap estimate is more dependent on monetary conditions. As a result, the gap is no longer positive around 2011 and its estimate is

substantially different in the subsequent, including the very recent, period. Worth mentioning is also the economic slack in the end of the sample, which appears a lot smaller with time-varying stds. Such a difference in the estimate of the output gap might have meaningful implications for policy projections.

\footnotetext{
${ }^{29}$ In Kalman filtration all standard deviations of shocks are re-scaled by a common constant to match the actual data. Without making the standard deviation high during the crisis, the scaling constant would high to match the data. As a result, it would increase the variance of all shocks over the whole sample with a risk of breaking the link between inflation and gaps.
} 
The filtration of the historical data along with the structure of the model enables to identify unobserved interest rates. Figure 11 compares interest rates consistent with the inflation

Figure 11: Estimates of unobserved nominal interest rates consistent with inflation targeting and money targeting strategies

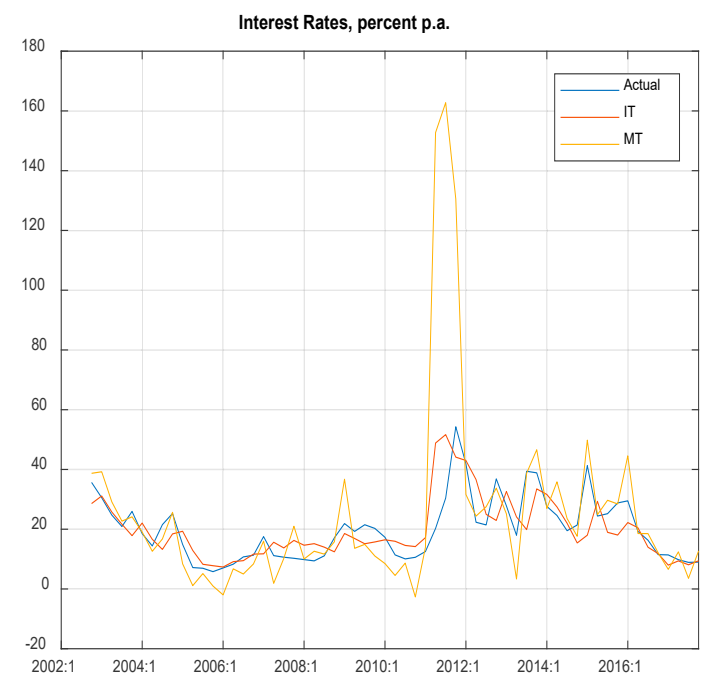

Source: Authors' calculations targeting $\left(i^{I T}\right)$ and the interest rates under the assumption of full adherence to the original money targets $\left(i^{M T}\right)$ with the actual overnight money market rate. The estimate of the interest rate consistent with inflation targeting is close to the actual rate, while the rate consistent with money targeting differs substantially. This difference is especially large during the periods of the 2011 crisis: had the central bank followed the original money growth target, it would have hiked the rate to a level a lot higher than the actual at that time. The fact that the actual rate is close to the estimate of the rate consistent with the inflation targeting strategy may indicate that in practice the National Bank smoothed the rates more than it would otherwise be implied by the money targeting strategy that is the monetary authorities only partially adhered to the money target.

\section{Historical decomposition to shocks}

Decomposition of the historical data to the effect of underlying structural shocks is another check of model properties and calibration. The structural shocks come from the filtration of the historical data. The decomposition then shows what shocks affected the dynamics of each variable. In a calibrated model with reasonable properties, the decomposition should show that the dynamics of a variable is not driven solely by its "own" shock, for example, inflation should not be solely explained by the cost push shock. Also, a story based on the decomposition should be intuitive. 
Figure 12: Historical Shock Decomposition of Inflation, percentage points

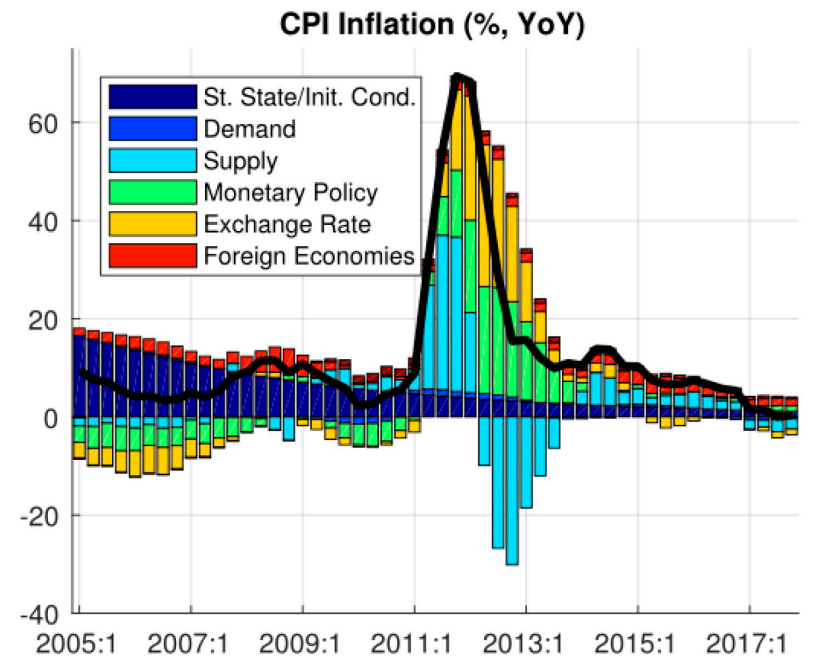

Source: Authors' calculations

Note: At each point of time contribution of shocks is depicted by bars. Bars sum up to the black solid line which is the actual data Composition of groups is as follows: (i) Demand and Supply - output gap shock, nominal wage growth shock, fiscal shocks, shocks to core and noncore inflation, relative price shock, (ii) Money demand money demand shock, (iii) Velocity - shock to velocity,(iv) MP Shocks - shocks to money and inflation targets, and (v) Ex. Rate and Foreign Ec. - UIP shock, foreign supply, demand, and monetary policy shocks.

The decomposition of YoY CPI inflation suggests that high inflation during the exchange rate crisis in 2011 is explained by exchange rate shocks, cost push shocks, and monetary policy shocks (Figure 12).

While the impact of the exchange rate shocks is consistent with sharp nominal depreciation during the crisis, the cost push shocks still reflect some impact of the business cycle, since our mode is a business cycle model by construction, and not a crisis model. Furthermore, positive contribution of monetary policy shocks to inflation during the crisis suggests ex-post accommodating monetary policy stance after the peak of inflation. Finally, the decomposition suggests that recent single digit inflation has been achieved as a result of tighter monetary policy (contribution of monetary policy shocks is small compared to the crisis) and by moderation of exchange rate depreciation. On the contrary, there are positive supply shocks recorded in 2015-2016 and also pro-inflationary external developments.

Figure 13: Historical Shock Decomposition of Output Gap, percentage points

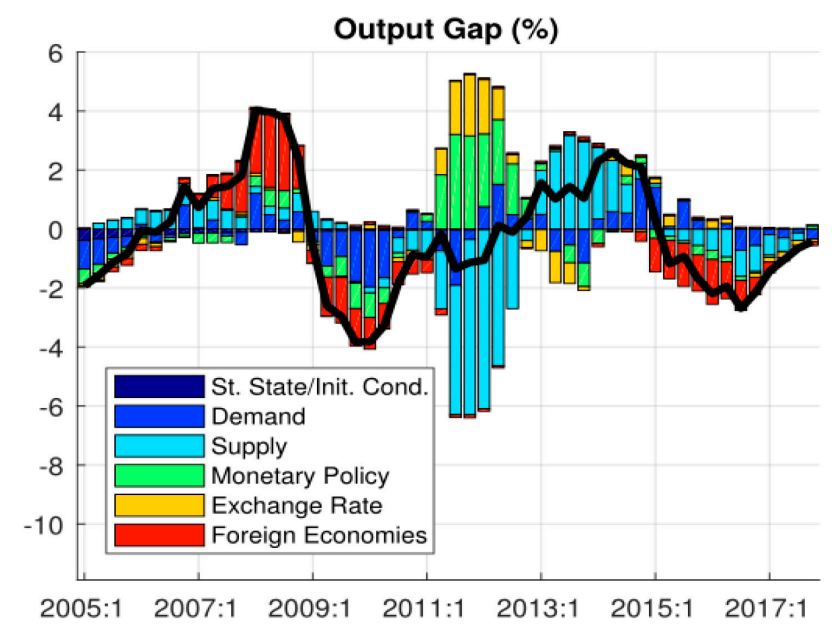

The decomposition of the output gap reveals factors behind its recent negative value (Figure 13). The negative output gap reflects a combination of factors, namely adverse external developments, tight monetary policy, supply shocks, and demand shocks. The demand shocks mirror recently diminishing flows of the directed loans, along with a low wage growth. 
Figure 14: Historical Shock Decomposition of Real Money Growth, percentage points Real Money Growth (\%, YoY)

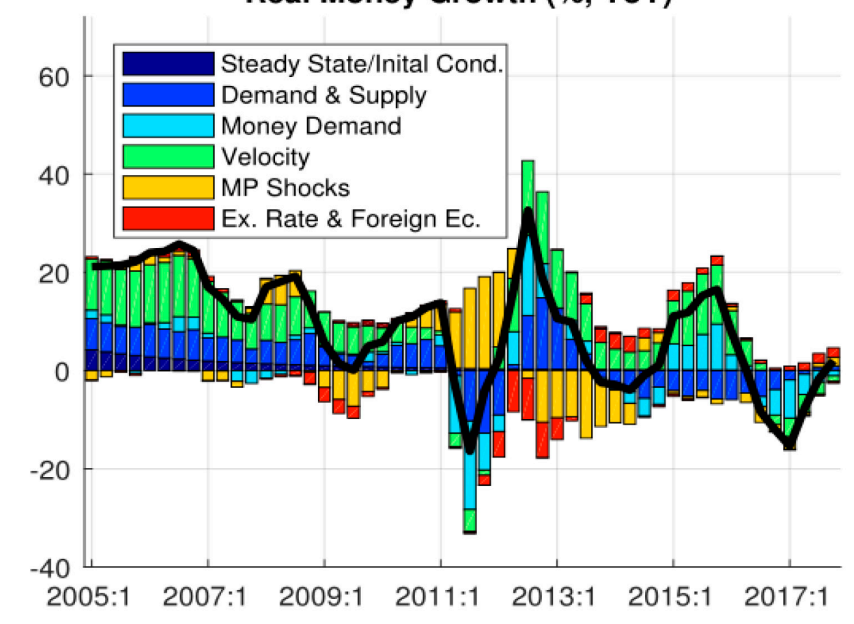

Source: Authors' computations
Decomposition also reveals that changes in velocity are the main driving force of the real money growth dynamics. The common business cycle shocks as demand and supply shocks are also significant, but the major contributors are velocity shocks, Figure 14. This aspect poses challenges to money targeting framework as the velocity might be difficult to predict. Effects of money demand shock are tiny as they explain high frequency movement in the data which is not present in YoY growth due to averaging. Current monetary policy

regime thus crucially depends on identification of the shocks in the velocity and their projection.

\section{CONCLUSIONS}

The NBRB considers modernizing monetary policy and transiting to an inflation targeting monetary policy strategy with an interest rate used as a key policy variable. These efforts are supported by developing an FPAS with a QPM at its core. A prototype of the QPM presented here is an extension of a canonical framework to account for particularities of macroeconomic policies and monetary policy transmission mechanism. The model allows for partial adherence to a money growth target, dollarization, managed exchange rate, includes wages, and fiscal and subsidized directed lending impulses. The QPM can therefore be employed for developing macroeconomic projections and estimating policy response by the NBRB required to bring inflation back to the inflation target over the monetary policy horizon. Moreover, the framework allows studying scenarios of an activist wage policy, fiscal expansion and intensification of directed lending, the policies that the government employed actively in the past, and inflationary impact of which may greatly complicate the central bank's task of achieving low and stable inflation. We emphasize that this model is not a pure forecasting device. Rather, it is a tool that helps to structure the monetary policy discussion, identify the impact of the key activity and inflation drivers, and focus on the forward-looking perspective, when deciding on the next monetary policy move. Evaluating macroeconomic risks, alternative scenarios and conducting monetary policy experiments - for example, allowing for greater exchange rate flexibility and tighter control over the interest rate - is another important area of model application in Belarus, which we plan to explore in our future research. 


\section{REFERENCES}

Amarasekara, C.,, Anand, R., Ehelepola, K., Ekanayake, H., Jayawickrema, V., Jegajeevan, S., Kober, C., Nugawela, T., Plotnikov, S., Remo, A., Venuganan, P. and R. Yatigammana, 2018, "An Open Economy Quarterly Projection Model for Sri Lanka," IMF Working Papers 18/149, International Monetary Fund.

Andrle, M., A. Berg, E. G. Berkes, R. A. Portillo, R.A. Morales, and J. Vlcek, 2013, "Money Targeting in a Modern Forecasting and Policy Analysis System; an Application to Kenya," IMF Working Papers 13/239, International Monetary Fund.

Andrle, M., Berg, A., Morales, R.A., Portillo, R. and Vlcek, J., 2013, "Forecasting and Monetary Policy Analysis in Low-Income Countries: Food and non-Food Inflation in Kenya", IMF Working Paper 13/61.

Benes, J., J. Hurnik, and D. Vavra, 2008. "Exchange Rate Management and Inflation Targeting: Modeling the Exchange Rate in Reduced-Form New Keynesian Models," Czech Journal of Economics and Finance (Finance a uver), Charles University Prague, Faculty of Social Sciences, vol. 58(03-04), pages 166-194, May.

Berg, A., P. D. Karam, and D. Laxton, 2006a, "Practical Model-Based Monetary Policy Analysis; A How-To Guide," IMF Working Papers 06/81, International Monetary Fund.

Berg, A., P. D. Karam, and D. Laxton., 2006b, "A Practical Model-Based Approach to Monetary Policy Analysis - Overview," IMF Working Papers 06/80, International Monetary Fund.

Benes, J., Clinton, K., Garcia-Saltos, R., Johnson, M., Laxton, D. Manchev, P. and T. Matheson, 2010, "Estimating Potential Output with a Multivariate Filter," IMF Working Paper No.10/285.

Benlamine, M., Bulíř, A., Farouki, M., Horbath, A., Hossaini, F. El Idrissi, H., Iraoui., Z., Kovac, M., Laxton, D., Maaroufi, A., Szilagyi, K., Taamouti, M. and D. Vavra, 2018, "Morocco: A Practical Approach to Monetary Policy Analysis in a Country with Capital Controls," IMF Working Paper No.18/27.

Bezborodova, A. and J. Vlček, 2018, “Identification of the neutral rate using bank lending rates: semi-structural model,” Bank Bulletin Magazine, Special Issue, 15.

Bulír, A., and J. Vlček, 2015, “Monetary Transmission: Are Emerging Market and Low Income Countries Different?” IMF Working Paper 15/239.

Czech National Bank “The Czech National Bank’s Forecasting and Policy Analysis System”.

Edited by W.Coats, D. Laxton, and D. Rose, Czech National Bank, 2013.

Clinton, K., T. Hlédik, T. Holub, D. Laxton, and H. Wang, 2017, “Czech Magic: Implementing Inflation-Forecast Targeting at the CNB," IMF Working Paper 17/21.

Djukic, M., T. Hledik, J. Polansky, L. Trajcev, and J. Vlcek, 2017. "A DSGE Model with Financial Dollarization - the Case of Serbia," Working Papers 2017/02, Czech National Bank. 
Erceg, C. J., D. W. Henderson, and A. T. Levin, 2000, "Optimal monetary policy with staggered wage and price contracts," Journal of Monetary Economics, Elsevier, vol. 46(2), pages 281-313, October.

International Monetary Fund "Annual Report on Exchange Arrangements and Exchange Restrictions," 2017.

International Monetary Fund "Conditionality in Evolving Monetary Policy Regimes," IMF Policy Paper, 2014.

International Monetary Fund "Evolving Monetary Policy Frameworks in Low-Income and Other Developing Countries," Staff Report, 2015.

International Monetary Fund "Republic of Belarus: Staff Report for the 2016 Article IV Consultation," 2016.

Kharitonchik, A. and D. Dmitriev, 2018, "Investigation of the Monetary Policy Transmission Mechanism in the Republic of Belarus,” Bank Bulletin Magazine, Special Issue, 13.

Koczan, Z., 2014, “Wage Dynamics in Belarus,” IMF Country Report - Selected Issues, 14/22 Miksjuk A., S. Ouliaris and M. Pranovich, 2015, “The Game of Anchors: Studying the Causes of Currency Crises in Belarus,” IMF Working Paper No.15/281. 


\section{Appendix A. Model Variables}

\begin{tabular}{|c|c|}
\hline Variable & Description \\
\hline $\bar{y}$ & Real GDP, $100 * \ln$ \\
\hline$\Delta y$ & Real GDP growth, annualized q-o-q, percent \\
\hline$\Delta \bar{y}$ & Potential GDP growth, annualized q-o-q, percent \\
\hline$\hat{y}$ & Output gap, percent \\
\hline$i$ & Domestic money market interest rate, percent per annum \\
\hline$i^{I T}$ & Inflation targeting implied interest rate, percent per annum \\
\hline$i^{M T}$ & Money targeting implied interest rate, percent per annum \\
\hline$i^{U I P}$ & UIP implied nominal interest rate, percent per annum \\
\hline$i^{\text {Neutral }}$ & Neutral level of the policy interest rate \\
\hline$\pi$ & Headline CPI inflation, annualized q-o-q, percent \\
\hline$\pi 4$ & Headline CPI inflation, y-o-y, percent \\
\hline$\pi^{T A R}$ & Inflation Target, y-o-y, percent \\
\hline$\pi^{C}$ & Core inflation, annualized q-o-q, percent \\
\hline$\pi^{N C}$ & Non-core inflation, annualized q-o-q, percent \\
\hline$r p$ & Relative prices: headline core CPI, percent \\
\hline$\widehat{r p}$ & Relative price gap, percent \\
\hline$E_{t} \pi_{t+i}$ & $\begin{array}{l}\text { Expected inflation for } i \text { quarters ahead based on information at time } t \text { annualized q-o- } \\
\mathrm{q}, \text { percent }\end{array}$ \\
\hline$p$ & Headline CPI, $100 * \ln$ \\
\hline rmci & Real monetary condition index, percent \\
\hline$S$ & Nominal effective exchange rate of Belarusian ruble, $100 * \ln$ \\
\hline$\Delta s^{T a r}$ & Nominal effective exchange rate target rate of change, annualized q-o-q, percent \\
\hline$\Delta w$ & Nominal wage growth, annualized q-o-q, percent \\
\hline$\widehat{r W}$ & Real wage gap, percent \\
\hline$w$ & Nominal wage, $100 * \ln$ \\
\hline$r w$ & Real wage, $100 * \ln$ \\
\hline$\overline{\Delta r w}$ & Equilibrium real wage growth, annualized q-o-q, percent \\
\hline$r m 3$ & Real M3 money, $100 * \ln$ \\
\hline$\Delta r m 3$ & Real M3 money growth, annualized q-o-q, percent \\
\hline$\widehat{r m 3}$ & Real M3 money gap, percent \\
\hline$v$ & Velocity of money, $100 * \ln$ \\
\hline$\Delta v$ & Velocity growth, annualized q-o-q, percent \\
\hline$\Delta r m 3^{T A R}$ & Real M3 growth target, annualized q-o-q, percent \\
\hline$\Delta m 3^{T A R}$ & Nominal M3 growth target, annualized q-o-q, percent \\
\hline$\hat{r}$ & Real interest rate gap, percent \\
\hline$\hat{r}^{F X}$ & Real effective interest rate gap - FX loans, percent p.a. \\
\hline$\Delta \bar{z}$ & Equilibrium real exchange rate depreciation, annualized q-o-q, percent \\
\hline$\hat{Z}$ & Real effective exchange rate gap, percent \\
\hline $\bar{r}^{F X}$ & Equilibrium real interest rate - FX loans, percent p.a. \\
\hline $\bar{r}^{\widetilde{E F}}$ & Equilibrium foreign real interest rate - FX loans weights, percent p.a. \\
\hline$\Delta \bar{z}^{\widetilde{E F}}$ & $\begin{array}{l}\text { Equilibrium real exchange rate depreciation - FX loans weights, annualized q-o-q, } \\
\text { percent }\end{array}$ \\
\hline$\pi^{E U}$ & Headline CPI inflation - EU, annualized q-o-q, percent \\
\hline$i^{E U}$ & Nominal interest rate - EU, percent p.a. \\
\hline$\hat{y}^{E U}$ & Output gap - EU, percent \\
\hline $\bar{r}^{E U}$ & Equilibrium real interest rate - EU, percent p.a. \\
\hline$\pi^{R U}$ & Headline CPI inflation - Russia, annualized q-o-q, percent \\
\hline
\end{tabular}




\begin{tabular}{|c|c|}
\hline$i^{R U}$ & Nominal interest rate - Russia, percent p.a. \\
\hline$\hat{y}^{R U}$ & Output gap - Russia, percent \\
\hline $\bar{r}^{R U}$ & Equilibrium real interest rate - Russia, percent p.a. \\
\hline$\pi^{U S}$ & Headline CPI inflation - the US, annualized q-o-q, percent \\
\hline$i^{U S}$ & Nominal interest rate - the US, percent p.a. \\
\hline $\bar{r}^{U S}$ & Equilibrium real interest rate - the US, percent p.a. \\
\hline$\widehat{r p}^{\text {Oil }}$ & Relative price of oil gap, percent \\
\hline$\overline{r p}{ }^{\text {Oil }}$ & Relative price of oil equilibrium, percent \\
\hline$p^{\text {Oil }}$ & World price of oil, $100 * \ln$ \\
\hline$\pi^{E X}$ & Effective foreign inflation, annualized q-o-q, percent \\
\hline$i^{E X}$ & Effective foreign interest rate, percent $\%$ p.a. \\
\hline$i^{\widetilde{E F}}$ & Effective foreign interest rate - FX loans weights, percent p.a. \\
\hline$\Delta s^{\widetilde{E F}}$ & $\begin{array}{l}\text { Effective nominal exchange rate depreciation - FX loans weights, annualized q-o-q, } \\
\text { percent }\end{array}$ \\
\hline prem & Country risk premium, percent \\
\hline$\overline{\text { prem }}$ & Equilibrium country risk premium, percent \\
\hline$D L$ & Direct lending, bln. BYN \\
\hline$B D$ & Budget deficit, bln. BYN \\
\hline NGDP & Nominal GDP, bln. BYN \\
\hline$d l 2 n g d p$ & Share of direct lending on nominal GDP, percent \\
\hline$b d 2 n g d p$ & Share of budget deficit on nominal GDP, percent \\
\hline$\Delta d l 2 n g d p$ & Change of share of direct lending on nominal GDP, percent \\
\hline$\Delta b d 2 n g d p$ & Change of share of budget deficit on nominal GDP, percent \\
\hline fdlimp & Fiscal and directed lending impulse, percent \\
\hline$\varepsilon^{\hat{y}}$ & Shock to domestic output gap, percent \\
\hline$\varepsilon^{\Delta \bar{y}}$ & Shock to the potential growth, percent \\
\hline$\varepsilon^{\Delta d l 2 n g d p}$ & Shock to the ratio of the stock of directed loans to nominal GDP, percent \\
\hline$\varepsilon^{\Delta b d 2 n g d p}$ & Shock to the ratio of budget deficit to nominal GDP, percent \\
\hline$\varepsilon^{\hat{y}^{\text {country_code }}}$ & Shock to foreign (EU, RU and the US) output gap, percent \\
\hline$\varepsilon^{\pi C}$ & Shock to core inflation, percent \\
\hline$\varepsilon^{\pi N C}$ & Shock to non-core inflation, percent \\
\hline$\varepsilon^{\pi}$ & $\begin{array}{l}\text { Technical residual in equation for headline inflation as a weighted average of core and } \\
\text { non-core inflation components, percent }\end{array}$ \\
\hline$\varepsilon^{\Delta \overline{r p}}$ & Shock to the rate of growth of relative prices, percent \\
\hline$\varepsilon^{\pi T A R}$ & Shock to inflation target, percent \\
\hline$\varepsilon^{\Delta w}$ & Shock to nominal wage growth, percent \\
\hline$\varepsilon^{\Delta \bar{r} w_{-} y}$ & Shock to the trend in the ratio of real wages to real GDP, percent \\
\hline$\varepsilon^{\pi^{\text {country_code }}}$ & Shock to foreign (EU, RU, and the US) inflation, percent \\
\hline$\varepsilon^{i I T}$ & Shock to the policy-rule-consistent domestic interest rate, percent \\
\hline$\varepsilon^{i}$ & Shock to nominal interest rate - monetary policy shock, percent \\
\hline$\varepsilon^{\overline{p r e m}}$ & Shock to the cyclical component (gap) of the UIP premium, percent \\
\hline$\varepsilon^{\overline{p r e m}}$ & Shock to the equilibrium level of the UIP premium, percent \\
\hline$\varepsilon^{i^{\text {country_code }}}$ & Shock to foreign (EU, RU, and the US) nominal interest rate, percent \\
\hline$\varepsilon^{\bar{r}^{\text {country_code }}}$ & Shock to foreign (EU, RU, and the US) equilibrium real interest rate, percent \\
\hline$\varepsilon^{\pi^{E X}}$ & $\begin{array}{l}\text { Technical residual in equation for foreign interest rate as a weighted average of } \\
\text { interest rates in RU, EU and the US, percent }\end{array}$ \\
\hline
\end{tabular}




\begin{tabular}{|c|l|}
\hline$\varepsilon^{S}$ & Shock to the nominal effective exchange rate, percent \\
\hline$\varepsilon^{\Delta s^{T A R}}$ & Shock to the nominal effective exchange rate target, percent \\
\hline$\varepsilon^{\Delta \bar{Z}}$ & Shock to the long-term rate of change in real effective exchange rate, percent \\
\hline$\varepsilon^{\Delta m 3}$ & Shock to nominal money balances, percent \\
\hline$\varepsilon^{\Delta r m 3}$ & Real money demand shock, percent \\
\hline$\varepsilon^{\Delta m 3^{T A R}}$ & Shock to the nominal money target, percent \\
\hline$\varepsilon^{\bar{r}^{F X}}$ & Shock to equilibrium level of the FX real interest rate, percent \\
\hline$\varepsilon^{\Delta \bar{v}}$ & Shock to the equilibrium level of velocity, percent \\
\hline$\varepsilon^{\widehat{r p p}^{\text {oil }}}$ & Shock to the cyclical component (gap) in relative oil prices, percent \\
\hline$\varepsilon^{\Delta \overline{r p}^{\text {oil }}}$ & Shock to the trend in relative oil prices, percent \\
\hline$\varepsilon^{\Delta s^{\text {eurusd }}}$ & Shock to the EURUSD nominal exchange rate, percent \\
\hline$\varepsilon^{\Delta s^{\text {usdrub }}}$ & Shock to the USDRUB nominal exchange rate, percent \\
\hline
\end{tabular}




\section{Appendix B. Model Equations}

$$
\begin{aligned}
& y_{t}=\hat{y}_{t}+\bar{y}_{t} \\
& \hat{y}_{t}=b_{1} \cdot E_{t}\left\{\hat{y}_{t+1}\right\}+b_{2} \cdot \hat{y}_{t-1}-b_{3} \cdot r m c i_{t}+b_{4} \cdot \hat{y}_{t}^{E X}+b_{5} \text { fqfimp }_{t}+b_{6} \widehat{r w}_{t-1}+\varepsilon_{t}^{\hat{y}} \\
& \Delta \bar{y}_{t}=\rho^{\Delta \bar{y}} \cdot \Delta \bar{y}_{t-1}+\left(1-\rho^{\Delta \bar{y}}\right) \cdot \Delta y_{s s}+\varepsilon_{t}^{\Delta \bar{y}} \\
& \Delta \bar{y}_{t}=4 \cdot\left(\bar{y}_{t}-\bar{y}_{t-1}\right) \\
& \Delta \bar{y}_{t}=\bar{y}_{t}-\bar{y}_{t-4} \\
& \Delta y_{t}=4 \cdot\left(y_{t}-y_{t-1}\right) \\
& \Delta y 4_{t}=y_{t}-y_{t-4} \\
& \Delta d l 2 n g d p_{t}=\rho^{d l} \cdot \Delta d l 2 n g d p_{t-1}+\varepsilon_{t}^{d l 2 n g d p} \\
& \Delta b d 2 n g d p_{t}=\rho^{b d} \cdot \Delta b d 2 n g d p_{t-1}+\varepsilon_{t}^{b d 2 n g d p} \\
& \text { fqfimp }_{t}=\Delta b d 2 n g d p_{t}+\Delta d l 2 n g d p_{t} \\
& i_{t}^{F X}=\operatorname{prem}_{t}^{c r}+i_{t}^{e x \_x} \\
& i_{t}^{e x_{-} f x}=w^{u s_{-} f x} \cdot i_{t}^{u s}+w^{e u_{-} f x} \cdot i_{t}^{e u}+\left(1-w^{u s_{-} f x}-w^{e u_{-} f x}\right) \cdot i_{t}^{r u} \\
& r_{t}^{F X}=i_{t}^{e x}+\Delta^{4} s_{t}+\left(w^{E U_{f x}}-w^{E U}\right) \cdot \Delta^{4} s_{t+1}^{\text {eurusd }}-\ldots \\
& \ldots-\left(1-w^{u s_{-} f x}-w^{e u_{-} f x}-w^{R U}\right) \cdot \Delta^{4} s_{t+1}^{u s d r u b}-E_{t} \pi 4_{t+1} \\
& \bar{r}_{t}^{F X}=\operatorname{prem}_{s s}^{c r}+w^{u s_{f x}} \cdot \bar{r}_{t}^{u s}+w^{e u_{f x}} \cdot \bar{r}_{t}^{e u}+\left(1-w^{u s_{f x}}-w^{e u_{f x}}\right) \cdot \bar{r}_{t}^{r u}+\cdots \\
& \ldots+w^{u s_{f x}} \cdot \pi_{s s}^{u s}+w^{e u_{f x}} \cdot \pi_{s s}^{e u}+\left(1-w^{u s_{f x}}-w^{e u_{f x}}\right) \cdot \pi_{s s}^{r u}+\Delta \bar{z}_{t}-\ldots \\
& \ldots-\left(w^{U S} \cdot \pi_{s S}^{u s}+w^{E U} \cdot \pi_{s S}^{e u}+w^{R U} \cdot \pi_{s S}^{r u}\right)-E_{t} \pi 4_{t+1}^{T A R} \\
& \hat{r}_{t}^{F X}=r_{t}^{F X}-\bar{r}_{t}^{F X} \\
& \hat{y}_{t}^{E X}=w^{r u_{-} G D P} \cdot \hat{y}_{t}^{R U}+\left(1-w^{r u_{-} G D P}\right) \cdot \hat{y}_{t}^{E U} \\
& r m c i_{t}=b_{21}\left(b_{22} \cdot \hat{r}_{t}+\left(1-b_{22}\right) \cdot \hat{r}_{t}^{F X}\right)+\left(1-b_{21}\right) \cdot \hat{z}_{t} \\
& \hat{y}_{t}^{R U}=\rho^{\hat{y}^{R U}} \cdot \hat{y}_{t-1}^{R U}+\varepsilon_{t}^{\hat{y}, R U} \\
& \hat{y}_{t}^{E U}=\rho^{\hat{y}^{E U}} \cdot \hat{y}_{t-1}^{E U}+\varepsilon_{t}^{\hat{y}, E U} \\
& \pi_{t}^{C}=a_{11} E_{t} \pi_{t+1}^{C}+\left(1-a_{11}\right) \pi_{t-1}^{C}+a_{12}\left\{a_{13}\left[a_{14} \hat{y}_{t}+\left(1-a_{14}\right) \widehat{r w}_{t}\right]+\cdots\right. \\
& \left.\ldots+\left(1-a_{13}\right)\left[\left(1-a_{15}\right)\left(\hat{z}_{t}-\widehat{r p}_{t}\right)+a_{15}\left(\widehat{r p}_{t}^{o i l}-\widehat{r p}_{t}\right)\right]\right\}+\varepsilon_{t}^{\pi, C} \\
& \pi_{t}^{N C}=a_{21} E_{t} \pi_{t+1}^{N C}+\left(1-a_{21}\right) \pi_{t-1}^{N C}+a_{22}\left\{a_{23}\left(\widehat{r p}_{t}^{o i l}+\hat{z}_{t}+\frac{w^{C}}{1-w^{C}} \widehat{r p}_{t}\right)+\cdots\right. \\
& \left.\ldots+\left(1-a_{23}\right)\left(\hat{z}_{t}+\frac{w^{C}}{1-w^{C}} \widehat{r p}_{t}\right)\right\}+\varepsilon_{t}^{\pi N C} \\
& \pi_{t}=w^{C} \cdot \pi_{t}^{C}+\left(1-w^{C}\right) \cdot \pi_{t}^{N C}+\varepsilon_{t}^{\pi} \\
& \pi 4_{t}^{C}=\left(\pi_{t}^{C}+\pi_{t-1}^{C}+\pi_{t-2}^{C}+\pi_{t-3}^{C}\right) / 4 \\
& \pi 4_{t}^{N C}=\left(\pi_{t}^{N C}+\pi_{t-1}^{N C}+\pi_{t-2}^{N C}+\pi_{t-3}^{N C}\right) / 4 \\
& \pi 4_{t}=\left(\pi_{t}+\pi_{t-1}+\pi_{t-2}+\pi_{t-3}\right) / 4 \\
& \pi_{t}^{C}=4 \cdot\left(p_{t}^{C}-p_{t-1}^{C}\right) \\
& \pi_{t}^{N C}=4 \cdot\left(p_{t}^{N C}-p_{t-1}^{N C}\right)
\end{aligned}
$$




$$
\begin{aligned}
& \pi_{t}=4 \cdot\left(p_{t}-p_{t-1}\right) \\
& r p_{t}=p_{t}^{C}-p_{t} \\
& r p_{t}=\overline{r p}_{t}+\widehat{r p}_{t} \\
& \Delta \overline{r p}_{t}=4 \cdot\left(\overline{r p}_{t}-\overline{r p}_{t-1}\right) \\
& \Delta \overline{r p}_{t}=\rho^{\Delta \overline{r p}} \cdot \Delta \overline{r p}_{t-1}+\left(1-\rho^{\Delta \overline{r p}}\right) \cdot \Delta r p_{s s}+\varepsilon_{t}^{\Delta \overline{r p}} \\
& \Delta r p_{t}=4 \cdot\left(r p_{t}-r p_{t-1}\right) \\
& \pi 4_{t}^{T A R}=\rho^{\pi 4^{T A R}} \cdot \pi 4_{t-1}^{T A R}+\left(1-\rho^{\pi 4^{T A R}}\right) \cdot \pi 4_{S S}^{T A R}+\varepsilon_{t}^{\pi^{T A R}} \\
& \Delta w_{t}=4 \cdot\left(w_{t}-w_{t-1}\right) \\
& \Delta^{4} w_{t}=w_{t}-w_{t-4} \\
& \Delta w_{t}=c_{1} E_{t}\left\{\Delta w_{t+1}\right\}+\left(1-c_{1}\right) \Delta w_{t-1}+c_{2} \hat{y}_{t}+c_{3} \widehat{r w}_{t}+\varepsilon_{t}^{\Delta w} \\
& r w_{t}=w_{t}-p_{t} \\
& r w_{t}=\overline{r w}_{t}+\widehat{r w}_{t} \\
& \Delta r w_{t}=4 \cdot\left(r w_{t}-r w_{t-1}\right) \\
& \overline{r w}_{-} y_{t}=\overline{r w}_{t}-\bar{y}_{t} \\
& \Delta{\overline{r w_{-} y_{t}}}_{t}=\rho^{\overline{r w_{-} y}} \cdot \Delta{\overline{r w_{-} y_{t-1}}}_{t}+\left(1-\rho^{\overline{r w_{-} y}}\right) \cdot \Delta{\overline{r w_{-} y_{s S}}}+\varepsilon_{t}^{\Delta \overline{r w_{-} y}} \\
& \pi_{t}^{R U}=4 \cdot\left(p_{t}^{R U}-p_{t-1}^{R U}\right) \\
& \pi_{t}^{R U}=\rho^{\pi^{R U}} \cdot \pi_{t-1}^{R U}+\left(1-\rho^{\pi^{R U}}\right) \cdot \pi_{S S}^{R U}+\varepsilon_{t}^{\pi^{R U}} \\
& \pi 4_{t}^{R U}=\left(\pi_{t}^{R U}+\pi_{t-1}^{R U}+\pi_{t-2}^{R U}+\pi_{t-3}^{R U}\right) / 4 \\
& \pi_{t}^{E U}=4 \cdot\left(p_{t}^{E U}-p_{t-1}^{E U}\right) \\
& \pi_{t}^{E U}=\rho^{\pi^{E U}} \cdot \pi_{t-1}^{E U}+\left(1-\rho^{\pi^{E U}}\right) \cdot \pi_{S S}^{E U}+\varepsilon_{t}^{\pi^{E U}} \\
& \pi 4_{t}^{E U}=\left(\pi_{t}^{E U}+\pi_{t-1}^{E U}+\pi_{t-2}^{E U}+\pi_{t-3}^{E U}\right) / 4 \\
& \pi_{t}^{U S}=4 \cdot\left(p_{t}^{U S}-p_{t-1}^{U S}\right) \\
& \pi_{t}^{U S}=\rho^{\pi^{U S}} \cdot \pi_{t-1}^{U S}+\left(1-\rho^{\pi^{U S}}\right) \cdot \pi_{S S}^{U S}+\varepsilon_{t}^{\pi^{U S}} \\
& \pi 4_{t}^{U S}=\left(\pi_{t}^{U S}+\pi_{t-1}^{U S}+\pi_{t-2}^{U S}+\pi_{t-3}^{U S}\right) / 4 \\
& \pi_{t}^{E X}=w^{R U} \cdot \pi_{t}^{R U}+w^{E U} \cdot \pi_{t}^{E U}+\left(1-w^{R U}-w^{E U}\right) \cdot \pi_{t}^{U S}+\varepsilon_{t}^{\pi E X} \\
& \pi 4_{t}^{E X}=\left(\pi_{t}^{E X}+\pi_{t-1}^{E X}+\pi_{t-2}^{E X}+\pi_{t-3}^{E X}\right) / 4 \\
& i_{t}^{I T}=g_{1} \cdot i_{t-1}^{I T}+\left(1-g_{1}\right) \cdot\left(i_{t}^{\text {Neutral }}+g_{2} \cdot\left(E_{t} \pi 4_{t+3}-E_{t} \pi 4_{t+3}^{T a r}\right)+g_{4} \cdot \hat{y}_{t}\right) \\
& i_{t}^{\text {Neutral }}=\bar{r}_{t}+E_{t} \pi 4_{t+3} \\
& i_{t}^{U I P}=E_{t} \Delta s_{t+1}+i_{t}^{E X}+\text { prem }_{t} \\
& i_{t}=w^{i} \cdot\left(m p r \cdot i_{t}^{I T}+(1-m p r) \cdot i_{t}^{M T}\right)+\left(1-w^{i}\right) \cdot i_{t}^{U I P} \\
& \text { prem }_{t}=\overline{\text { prem }}_{t}+\overline{\text { prem }}_{t} \\
& \widehat{\text { prem }}_{t}=\rho^{\text {prem }} \cdot \widehat{\text { prem }}_{t-1}+\varepsilon_{t}^{\text {prem }} \\
& \overline{\text { prem }}_{t}=\rho^{\overline{\text { prem }}} \cdot \overline{\text { prem }}_{t-1}+\left(1-\rho^{\overline{\text { prem }}}\right) \cdot \overline{\text { prem }}_{s s}+\varepsilon_{t}^{\overline{\text { prem }}}
\end{aligned}
$$




$$
\begin{aligned}
& i_{t}^{R U}=\rho^{i^{R U}} \cdot i_{t-1}^{R U}+\left(1-\rho^{i^{R U}}\right) \cdot\left(r_{s S}^{R U}+\pi_{s S}^{R U}\right)+\varepsilon_{t}^{i^{R U}} \\
& r_{t}^{R U}=i_{t}^{R U}-E_{t} \pi 4_{t+1}^{R U} \\
& \bar{r}_{t}^{R U}=\rho^{\bar{r}^{R U}} \cdot \bar{r}_{t-1}^{R U}+\left(1-\rho^{\bar{r}^{R U}}\right) \cdot r_{s S}^{R U}+\varepsilon_{t}^{\bar{r}^{R U}} \\
& \hat{r}_{t}^{R U}=r_{t}^{R U}-\bar{r}_{t}^{R U} \\
& i_{t}^{E U}=\rho^{i^{E U}} \cdot i_{t-1}^{E U}+\left(1-\rho^{i^{E U}}\right) \cdot\left(r_{s S}^{E U}+\pi_{s S}^{E U}\right)+\varepsilon_{t}^{i^{E U}} \\
& r_{t}^{E U}=i_{t}^{E U}-E_{t} \pi 4_{t+1}^{E U} \\
& \bar{r}_{t}^{E U}=\rho^{\bar{r}^{E U}} \cdot \bar{r}_{t-1}^{E U}+\left(1-\rho^{\bar{r}^{E U}}\right) \cdot r_{s S}^{E U}+\varepsilon_{t}^{\bar{r}^{E U}} \\
& \hat{r}_{t}^{E U}=r_{t}^{E U}-\bar{r}_{t}^{E U} \\
& i_{t}^{U S}=\rho^{i^{U S}} \cdot i_{t-1}^{U S}+\left(1-\rho^{i^{U S}}\right) \cdot\left(r_{S S}^{U S}+\pi_{S S}^{U S}\right)+\varepsilon_{t}^{i^{U S}} \\
& r_{t}^{U S}=i_{t}^{U S}-E_{t} \pi 4_{t+1}^{U S} \\
& \bar{r}_{t}^{U S}=\rho^{\bar{r}^{U S}} \cdot \bar{r}_{t-1}^{U S}+\left(1-\rho^{\bar{r} U S}\right) \cdot r_{S S}^{U S}+\varepsilon_{t}^{\bar{r}^{U S}} \\
& \hat{r}_{t}^{U S}=r_{t}^{U S}-\bar{r}_{t}^{U S} \\
& i_{t}^{E X}=w^{R U} \cdot i_{t}^{R U}+w^{E U} \cdot i_{t}^{E U}+\left(1-w^{R U}-w^{E U}\right) \cdot i_{t}^{U S}+\varepsilon_{t}^{i E X} \\
& \hat{r}_{t}^{E X}=r_{t}^{E X}-\bar{r}_{t}^{E X} \\
& r_{t}=i_{t}-E_{t} \pi 4_{t+1} \\
& \hat{r}_{t}=r_{t}-\bar{r}_{t} \\
& \bar{r}_{t}=\bar{r}_{t}^{E X}+\overline{\text { rrem }}_{t}+E_{t}\left\{\Delta \bar{z}_{t+1}\right\} \\
& s_{t}=(1-e p r) \cdot\left(s_{t-1}+\Delta s_{t}^{T a r}\right)+e p r \cdot\left(e_{1} \cdot\left(s_{t-1}+\Delta \bar{z}_{t}+\pi_{t}-\pi_{t}^{E X}\right)+\ldots\right. \\
& \left.\ldots+\left(1-e_{1}\right) \cdot E_{t} s_{t+1}-\frac{i_{t}}{4}+\frac{i_{t}^{E X}}{4}+\frac{\text { prem }_{t}}{4}\right)+\varepsilon_{t}^{s} \\
& \Delta^{4} s_{t}=s_{t}-s_{t-4} \\
& \Delta s_{t}=4 \cdot\left(s_{t}-s_{t-1}\right) \\
& \Delta s_{t}=\Delta z_{t}+\pi_{t}-\pi_{t}^{E X} \\
& \Delta s_{t}^{T a r}=\rho^{\Delta s^{T A R}} \cdot \Delta s_{t}^{T a r}+\left(1-\rho^{\Delta s^{T A R}}\right) \cdot\left(\Delta \bar{z}_{t}+\pi_{t}^{T a r}-\pi_{t}^{E X}\right)+\varepsilon_{t}^{\Delta s^{T a r}} \\
& z_{t}=\bar{z}_{t}+\hat{z}_{t} \\
& \Delta \bar{z}_{t}=4 \cdot\left(\bar{z}_{t}-\bar{z}_{t-1}\right) \\
& \Delta \bar{z}_{t}=\rho^{\Delta \bar{z}} \cdot \Delta \bar{z}_{t-1}+\left(1-\rho^{\Delta \bar{z}}\right) \cdot \Delta z_{s S}+\varepsilon_{t}^{\Delta \bar{z}} \\
& \Delta^{4} \bar{z}_{t}=\bar{z}_{t}-\bar{z}_{t-4} \\
& \Delta r m 3_{t}=4 \cdot\left(r m 3_{t}-r m 3_{t-1}\right) \\
& \Delta^{4} r m 3_{t}=4 \cdot\left(r m 3_{t}-r m 3_{t-4}\right) \\
& \Delta \mathrm{rm} 3_{t}=\Delta y_{t}+\gamma_{1} \cdot\left[\left(i_{t}-i_{t}^{\text {Neutral }}\right)-\left(i_{t-1}-i_{t-1}^{\text {Neutral }}\right)\right]+\gamma_{2} \cdot \widehat{r m 3}_{t-1}-\Delta \bar{v}_{t} \\
& +\varepsilon_{t}^{\Delta r m 3} \\
& \overline{r m 3}_{t}=r m 3_{t}-\left(y_{t}+\gamma_{1} \cdot\left(i_{t}-i_{t}^{\text {Neutral }}\right)-\bar{v}_{t}\right) \\
& \Delta r m 3_{t}^{\text {Tar }}=E_{t-1}\left\{y_{t}\right\}-E_{t-1}\left\{\Delta \bar{v}_{t}\right\}
\end{aligned}
$$




$$
\begin{aligned}
& \Delta m 3_{t}^{\text {Tar }}=\Delta r m 3_{t}^{\text {Tar }}+E_{t-1}\left\{\pi 4_{t}^{T A R}\right\}+E_{t-1}\left\{\varepsilon_{t}^{\Delta r m 3}\right\} \\
& \Delta m 3_{t}^{T A R}=\Delta y_{t}+\pi_{t}+\gamma_{1} \cdot\left\{\left(i_{t}^{M T}-i_{t}^{\text {Neutral }}\right)-\left(i_{t-1}-i_{t-1}^{\text {Neutral }}\right)\right\}-\cdots \\
& \ldots-\gamma_{2} \cdot \widehat{r m 3}_{t-1} \Delta \bar{v}_{t}+\varepsilon_{t}^{\Delta r m 3} \\
& v_{t}=\hat{v}_{t}+\bar{v}_{t} \\
& \Delta v_{t}=4 \cdot\left(v_{t}-v_{t-1}\right) \\
& \Delta \bar{v}_{t}=4 \cdot\left(\bar{v}_{t}-\bar{v}_{t-1}\right) \\
& \Delta \bar{v}_{t}=\rho^{\Delta \bar{v}} \Delta \bar{v}_{t-1}+\left(1-\rho^{\Delta \bar{v}}\right) \cdot \Delta v_{S S}+\varepsilon_{t}^{\Delta \bar{v}} \\
& \hat{v}_{t}=\rho^{\hat{v}} \cdot \hat{v}_{t-1}+\varepsilon_{t}^{\hat{v}} \\
& r p_{t}^{\text {oil }}=p_{t}^{\text {oil }}-\left(w^{R U} p_{t}^{R U}+w^{E U} p_{t}^{E U}+\left(1-w^{R U}-w^{E U}\right) p_{t}^{U S}\right) \\
& \widehat{r p}_{t}^{o i l}=r p_{t}^{o i l}-\overline{r p}_{t}^{\text {oil }} \\
& \Delta \overline{r p}_{t}^{o i l}=4 \cdot\left(\overline{r p}_{t}^{o i l}-\overline{r p}_{t-1}^{o i l}\right) \\
& \widehat{r p}_{t}^{\text {oil }}=\rho^{\widehat{r p}^{\text {oil }}} \cdot \widehat{r p}_{t-1}^{\text {oil }}+\varepsilon_{t}^{\widehat{r p}^{\text {oil }}} \\
& \Delta \overline{r p}_{t}^{\text {oil }}=\rho^{\Delta \bar{r}^{\text {oil }}} \cdot \Delta \bar{r}_{t-1}^{\text {oil }}+\left(1-\rho^{\Delta \bar{r} \bar{p}^{o i l}}\right) \cdot \Delta \overline{r p}_{s s}^{\text {oil }}+\varepsilon_{t}^{\Delta \overline{r p}^{\text {oil }}} \\
& \Delta r p_{t}^{\text {oil }}=4 \cdot\left(r p_{t}^{\text {oil }}-r p_{t-1}^{\text {oil }}\right) \\
& \Delta s_{t}^{\text {eurusd }}=\rho^{\Delta s^{\text {eurusd }}} \cdot \Delta s_{t+1}^{\text {eurusd }}+\varepsilon_{t}^{\Delta s^{\text {eurusd }}} \\
& \Delta s_{t}^{\text {eurusd }}=4 \cdot\left(s_{t}^{\text {eurusd }}-s_{t-1}^{\text {eurusd }}\right) \\
& \Delta^{4} s_{t}^{\text {eurusd }}=s_{t}^{\text {eurusd }}-s_{t-1}^{\text {eurusd }} \\
& \Delta s_{t}^{u s d r u b}=\rho^{\Delta s^{u s d r u b}} \cdot \Delta s_{t+1}^{u s d r u b}+\varepsilon_{t}^{\Delta s}{ }^{u s d r u b} \\
& \Delta s_{t}^{u s d r u b}=4 \cdot\left(s_{t}^{u s d r u b}-s_{t-1}^{u s d r u b}\right) \\
& \Delta^{4} s_{t}^{u s d r u b}=s_{t}^{u s d r u b}-s_{t-1}^{u s d r u b}
\end{aligned}
$$


Appendix C. Calibration of the Model Coefficients

\begin{tabular}{|c|c|c|c|}
\hline Coefficient & Value & Coefficient & Value \\
\hline \multicolumn{2}{|c|}{ Output gap } & \multicolumn{2}{|c|}{$\begin{array}{l}\text { Monetary policy and } \\
\text { exchange rate regimes }\end{array}$} \\
\hline$b_{1}$ & 0.1 & epr & 0.7 \\
\hline$b_{2}$ & 0.6 & $m p r$ & 0.5 \\
\hline$b_{3}$ & 0.1 & \multicolumn{2}{|c|}{ Monetary policy block } \\
\hline$b_{4}$ & 0.2 & $g_{1}$ & 0.6 \\
\hline$b_{5}$ & 0.3 & $g_{2}$ & 1.5 \\
\hline$b_{6}$ & 0.1 & $g_{3}$ & 0.5 \\
\hline \multicolumn{2}{|c|}{ Core inflation } & \multicolumn{2}{|c|}{$\begin{array}{c}\text { Real monetary condition } \\
\text { index }\end{array}$} \\
\hline$a_{11}$ & 0.3 & $b_{21}$ & 0.5 \\
\hline$a_{12}$ & 0.5 & $b_{22}$ & 0.6 \\
\hline$a_{13}$ & 0.75 & \multicolumn{2}{|c|}{ Money demand } \\
\hline$a_{14}$ & 0.6 & $\gamma_{1}$ & 0.6 \\
\hline \multicolumn{2}{|c|}{ Non-core inflation } & $\gamma_{2}$ & 0.3 \\
\hline$a_{21}$ & 0.7 & \multirow{2}{*}{\multicolumn{2}{|c|}{ Wage growth }} \\
\hline$a_{22}$ & 0.1 & & \\
\hline$a_{23}$ & 0.35 & $c_{1}$ & 0.5 \\
\hline \multicolumn{2}{|c|}{$U I P$} & $c_{2}$ & 0.5 \\
\hline$e_{1}$ & 0.45 & $c_{3}$ & 0.5 \\
\hline
\end{tabular}




\section{Appendix D. Relationship between the trade-weighted nominal effective exchange rate and} the nominal effective exchange rate with weights according to the currency structure of

\section{FX-denominated loans}

The model operates the nominal effective exchange rate, which is a trade-weighted average of three bilateral rates $s_{t}^{u s d b y n}, s_{t}^{\text {eurbyn }}$ and $s_{t}^{\text {rurbyn }}$

$$
s_{t}=w^{U S} \cdot s_{t}^{\text {usdbyn }}+w^{E U} \cdot s_{t}^{\text {eurbyn }}+\left(1-w^{U S}-w^{E U}\right) \cdot s_{t}^{\text {rurbyn }}
$$

To keep the model parsimonious, we do not model these bilateral exchange rates. Hence, we need to directly link the trade-weighted nominal exchange rate to the effective nominal exchange rate $s_{t}$ with weights consistent with the currency structure of FX-loans $s_{t}^{E F}$. For that we first express each bilateral exchange rate from (C.1) in terms of the effective rate and cross exchange rates $s_{t}^{\text {eurusd }}$ and $s_{t}^{u s d r u r}$ For example, for $s_{t}^{u s d b y n}$ :

$$
\begin{gathered}
s_{t}=w^{U S} \cdot s_{t}^{\text {bynusd }}+w^{E U} \cdot s_{t}^{\text {byneur }}+\left(1-w^{U S}-w^{E U}\right) \cdot s_{t}^{\text {bynrur }}= \\
=w^{U S} \cdot s_{t}^{\text {bynusd }}+w^{E U} \cdot\left(s_{t}^{\text {bynusd }}+s_{t}^{\text {usdeur }}\right)+\left(1-w^{U S}-w^{E U}\right) \cdot\left(s_{t}^{\text {bynusd }}+s_{t}^{\text {usdrur }}\right)
\end{gathered}
$$

Then $s_{t}^{u s d b y n}$ :

$$
s_{t}^{u s d b y n}=s_{t}-w^{E U} \cdot s_{t}^{u s d e u r}+\left(1-w^{U S}-w^{E U}\right) \cdot s_{t}^{u s d r u r}
$$

By analogy,

$$
s_{t}^{\text {byneur }}=s_{t}+w^{U S} \cdot s_{t}^{\text {usdeur }}-\left(1-w^{U S}-w^{E U}\right) \cdot\left(s_{t}^{\text {usdrur }}-s_{t}^{\text {usdeur }}\right)
$$

and

$$
s_{t}^{\text {bynrur }}=s_{t}+w^{U S} \cdot s_{t}^{\text {usdrur }}-w^{E U} \cdot\left(s_{t}^{\text {usdeur }}+s_{t}^{\text {usdrur }}\right)
$$

Substituting expressions for the bilateral rates in

$$
s_{t}=w^{U S_{f x}} \cdot s_{t}^{u s d b y n}+w^{E U_{f x}} \cdot s_{t}^{\text {eurbyn }}+\left(1-w^{U S_{f x}}-w^{E U_{f x}}\right) \cdot s_{t}^{\text {rurbyn }}
$$

and rearranging gives

$$
\begin{array}{r}
s_{t}^{\widetilde{E F}}=s_{t}+s_{t}^{\text {usdeur }} \cdot\left(w^{E U_{f x}}-w^{E U}\right)+s_{t}^{\text {rurusd }} \cdot \ldots \\
\ldots \cdot\left\{\left(w^{U S}+w^{E U}\right)-\left(w^{U S_{f x}}+w^{E U_{f x}}\right)\right\},
\end{array}
$$

which links two nominal exchange rates.

The relationship is then used to model the definition of real effective interest rate on the FXdenominated loans (equation (13) in appendix B):

$$
\begin{gathered}
r_{t}^{F X}=i_{t}^{e x_{f x}}+\Delta^{4} s_{t}+\left(w^{E U_{f x}}-w^{E U}\right) \cdot \Delta^{4} s_{t+1}^{u s d e u r}-\ldots \\
\ldots-\left(1-w^{u s_{-} f x}-w^{e u_{-} f x}-w^{R U}\right) \cdot \Delta^{4} s_{t+1}^{r u b r u s d}-E_{t} \pi 4_{t+1}
\end{gathered}
$$

